\title{
Short-lived brominated hydrocarbons - observations in the source regions and the tropical tropopause layer
}

\author{
S. Brinckmann ${ }^{1}$, A. Engel ${ }^{1}$, H. Bönisch ${ }^{1}$, B. Quack ${ }^{2}$, and E. Atlas ${ }^{3}$ \\ ${ }^{1}$ Institute for Atmospheric and Environmental Sciences, Universität Frankfurt/Main, Germany \\ ${ }^{2}$ Leibniz-Institut für Meereswissenschaften, Universität Kiel, Germany \\ ${ }^{3}$ Rosenstiel School of Marine and Atmospheric Science, University of Miami, USA \\ Correspondence to: S. Brinckmann (s.brinckmann@iau.uni-frankfurt.de)
}

Received: 7 June 2011 - Published in Atmos. Chem. Phys. Discuss.: 5 August 2011

Revised: 12 December 2011 - Accepted: 9 January 2012 - Published: 1 February 2012

\begin{abstract}
We conducted measurements of the five important short-lived organic bromine species in the marine boundary layer (MBL). Measurements were made in the Northern Hemisphere mid-latitudes (Sylt Island, North Sea) in June 2009 and in the tropical Western Pacific during the TransBrom ship campaign in October 2009. For the one-week time series on Sylt Island, mean mixing ratios of $\mathrm{CHBr}_{3}$, $\mathrm{CH}_{2} \mathrm{Br}_{2}, \mathrm{CHBr}_{2} \mathrm{Cl}$ and $\mathrm{CH}_{2} \mathrm{BrCl}$ were 2.0, 1.1, 0.2, $0.1 \mathrm{ppt}$, respectively. We found maxima of 5.8 and $1.6 \mathrm{ppt}$ for the two main components $\mathrm{CHBr}_{3}$ and $\mathrm{CH}_{2} \mathrm{Br}_{2}$. Along the cruise track in the Western Pacific (between $41^{\circ} \mathrm{N}$ and $13^{\circ} \mathrm{S}$ ) we measured mean mixing ratios of $0.9,0.9,0.2,0.1$ and $0.1 \mathrm{ppt}$ for $\mathrm{CHBr}_{3}, \mathrm{CH}_{2} \mathrm{Br}_{2}, \mathrm{CHBrCl}_{2}, \mathrm{CHBr}_{2} \mathrm{Cl}$ and $\mathrm{CH}_{2} \mathrm{BrCl}$. Air samples with coastal influence showed considerably higher mixing ratios than the samples with open ocean origin. Correlation analyses of the two data sets yielded strong linear relationships between the mixing ratios of four of the five species (except for $\mathrm{CH}_{2} \mathrm{BrCl}$ ). Using a combined data set from the two campaigns and a comparison with the results from two former studies, rough estimates of the molar emission ratios between the correlated substances were: 9/1/0.35/0.35 for $\mathrm{CHBr}_{3} / \mathrm{CH}_{2} \mathrm{Br}_{2} / \mathrm{CHBrCl}_{2} / \mathrm{CHBr}_{2} \mathrm{Cl}$. Additional measurements were made in the tropical tropopause layer (TTL) above Teresina (Brazil, $5^{\circ} \mathrm{S}$ ) in June 2008, using balloon-borne cryogenic whole air sampling technique. Near the level of zero clear-sky net radiative heating (LZRH) at $14.8 \mathrm{~km}$ about $2.25 \mathrm{ppt}$ organic bromine was bound to the five short-lived species, making up $13 \%$ of total organic bromine (17.82 ppt). $\mathrm{CH}_{2} \mathrm{Br}_{2}(1.45 \mathrm{ppt})$ and $\mathrm{CHBr}_{3}(0.56 \mathrm{ppt}) \mathrm{ac}-$ counted for $90 \%$ of the budget of short-lived compounds in that region. Near the tropopause (at $17.5 \mathrm{~km}$ ) organic
\end{abstract}

bromine from these substances was reduced to $1.35 \mathrm{ppt}$, with 1.07 and $0.12 \mathrm{ppt}$ attributed to $\mathrm{CH}_{2} \mathrm{Br}_{2}$ and $\mathrm{CHBr}_{3}$, respectively.

\section{Introduction}

Reactive halogens, especially chlorine and bromine compounds, contribute to the decomposition of stratospheric ozone. In addition to mainly anthropogenic long-lived source gases like chlorofluorocarbons (CFC), chlorocarbons, or bromofluorocarbons (Halon fire suppressants), other substances with atmospheric lifetimes shorter than six months, often referred to as very short-lived substances (VSLS), have the potential to transport a significant amount of reactive halogen into the stratosphere. A significant impact to the stratospheric bromine budget is expected from brominated VSLS species, whose sources are predominantly natural. Bromoform $\left(\mathrm{CHBr}_{3}\right)$, dibromomethane $\left(\mathrm{CH}_{2} \mathrm{Br}_{2}\right)$ and the three polyhalogenated species $\mathrm{CHBr}_{2} \mathrm{Cl}, \mathrm{CHBrCl}_{2}$ and $\mathrm{CH}_{2} \mathrm{BrCl}$ have been identified as the most important short-lived carriers of atmospheric bromine. Highest concentrations of brominated VSLS are usually found in coastal regions, which is commonly attributed to emissions from macroalgae (Montzka et al., 2011). Typically lower values have been measured above the open ocean (e.g. Quack and Wallace, 2004), except for certain upwelling regions (e.g. Class and Ballschmiter, 1988; Quack et al., 2004; Carpenter et al., 2007), where a high abundance of phytoplankton is expected to account for strong emissions of these bromocarbons. Several studies (e.g. Yokouchi et al., 2005; O’Brien 
et al., 2009) have found good correlations for at least three of the brominated VSLS $\left(\mathrm{CHBr}_{3}, \mathrm{CH}_{2} \mathrm{Br}_{2}\right.$ and $\left.\mathrm{CHBr}_{2} \mathrm{Cl}\right)$, which suggests common sources and consistent emission ratios between these compounds.

There is a large uncertainty about the amount of bromine transported into the stratosphere by brominated VSLS. Very few measurements of these species in the entrance region to the stratosphere have been published to date (e.g. Schauffler et al., 1999; Laube et al., 2008; Liang et al., 2010). Based on organic bromine source gas data in the tropical tropopause layer (TTL) and the results from modeling studies concerning the transport of these gases and their degradation products into the stratosphere, Montzka et al. (2011) have determined that brominated VSLS contribute between 1 and $8 \mathrm{ppt}$ to stratospheric inorganic bromine $\left(\mathrm{Br}_{\mathrm{y}}\right)$. Stratospheric measurements of $\mathrm{BrO}$ (one of the main products resulting from the degradation of the VSLS) have indicated values of about 3-7 ppt $\mathrm{Br}_{\mathrm{y}}$ that could be attributed to this additional input from VSLS (Dorf et al., 2006). Because of large variability in source emissions and uncertainty in quantifying transport pathways to the upper tropical troposphere, determination of the global transport of reactive halogens through the TTL and into the stratosphere is a difficult issue. Several studies emphasise the importance of certain regions, in particular the Western Pacific region, on the transport of VSLS from the source areas to the TTL (Gettelman et al., 2002; Fueglistaler et al., 2004; Aschmann et al., 2009). These observations underline the necessity and importance of VSLS measurements in the marine boundary layer (MBL) and in the TTL of these specific regions to improve the quantitative understanding of the troposphere-to-stratosphere transport of bromine from VSLS.

\section{Measurements}

\subsection{Sampling and analysis}

Two-litre electropolished stainless steel canisters of the same type were used for both the Sylt Island and TransBrom sample collection. The one-week air sampling campaign in List on the island of Sylt (North Sea, $55.02^{\circ} \mathrm{N}, 8.43^{\circ} \mathrm{E}, 2 \mathrm{~m}$ a.s.l.) was performed in June 2009. 46 air samples were collected between 22 June 18:00 UTC and 29 June 09:00 UTC, with a time resolution of three hours (except for a break between 21:00 and 03:00 at night). The sampling was carried out about $100 \mathrm{~m}$ from the eastern coast of Sylt Island. This eastern coastline is characterized by tidal flats, while the western coast is oriented to the open sea. The evacuated canisters were opened and flushed with ambient air for about $20 \mathrm{~s}$. Using a reciprocating pump, the canisters were then filled to a pressure of approximately 2.5 bar. About one week after the measurement campaign the air samples were analysed at the Institut für Atmosphäre und Umwelt (IAU) Frankfurt using an Agilent-7890 gas chromatography system with mass

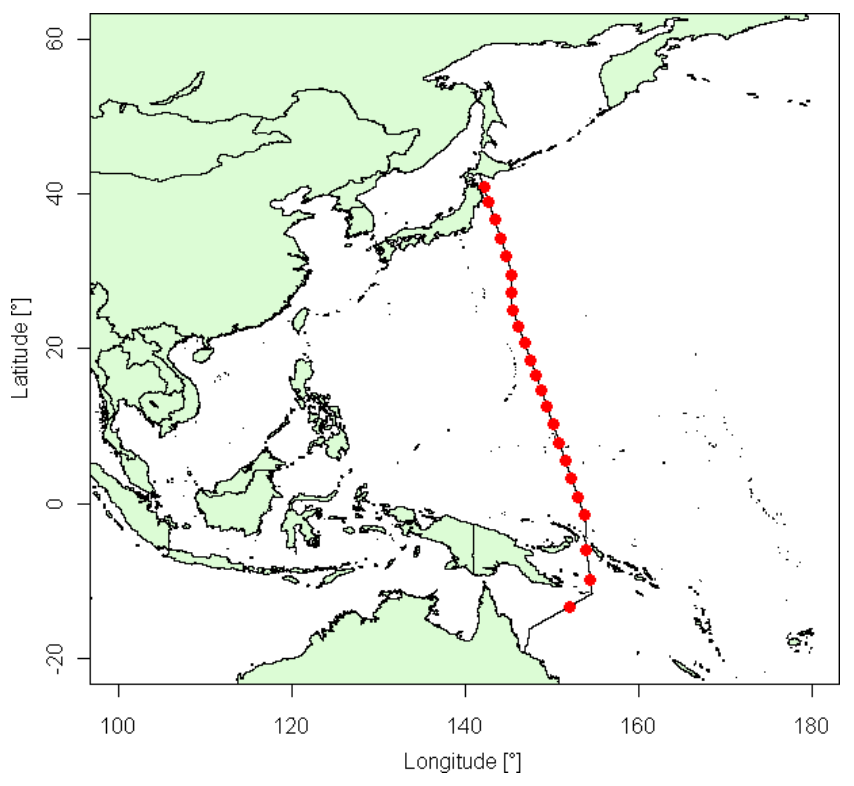

Fig. 1. Cruise track of research ship "Sonne" during "TransBrom" measurement campaign in October 2009. The red dots mark the location of the 23 air samplings for the IAU Frankfurt dataset.

spectrometric detection (GC-MSD) in electron impact ionisation (EI) mode. We obtained mixing ratio time series for four of the brominated VSLS: $\mathrm{CH}_{2} \mathrm{Br}_{2}, \mathrm{CHBr}_{3}, \mathrm{CHBr}_{2} \mathrm{Cl}$ and $\mathrm{CH}_{2} \mathrm{BrCl}$.

During the TransBrom measurement campaign aboard the research vessel "Sonne" in the West Pacific in October 2009 (see overview paper by Krüger and Quack, 2012) we collected 23 air samples between $41^{\circ} \mathrm{N}$ and $13^{\circ} \mathrm{S}$ latitude. The track of the ship and the coordinates of the sampling locations are illustrated in Fig. 1. The sampling started near the northern coast of the Japanese main island Honshu and ended about $300 \mathrm{~km}$ southeast of the coast of Papua New Guinea. Using a metal bellows pump, the sample canisters were flushed five times before being filled to the final sample pressure of 2 bar. The air samples were collected two times per day, at around 11:00 and 23:00 UTC (21:00 and 09:00 LT), during the last three days only one sampling per day (at 23:00 UTC) was carried out. The measurements were conducted on 14 January 2010 at the IAU using the aforementioned GC-MSD system in negative ion chemical ionisation (NCI) mode. With this detection mode we could achieve a very precise analysis at very low detection limits of all five brominated VSLS. Figure 2 shows a NCI chromtogram for bromine ion mass 79 as obtained during the TransBrom measurements.

During the same campaign in the Western Pacific an additional set of air samples was collected using 2.3-litre electropolished stainless steel canisters. The sampling procedure was the same as described above for the TransBrom IAU data set. The measurements were conducted at the University of 


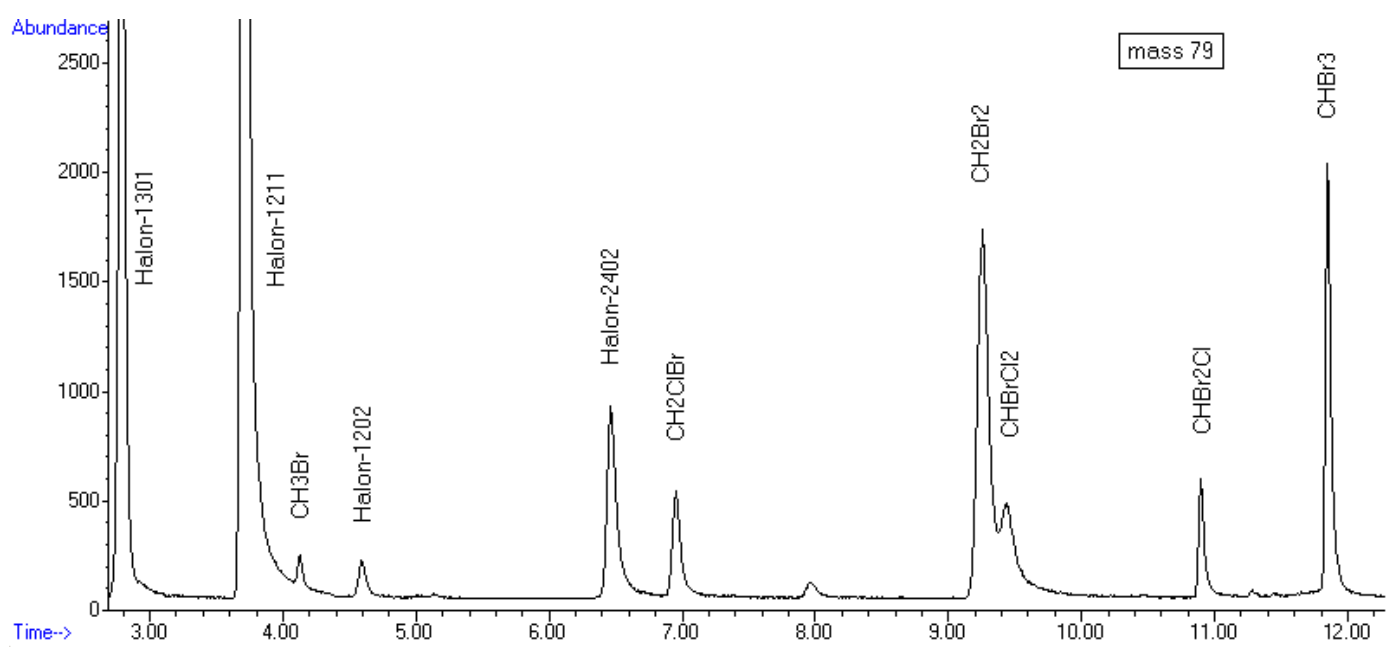

Fig. 2. Chromatogram in NCI mode on Br ion mass 79 during TransBrom measurements.

Miami using a HP 5971 GC/MSD system in EI mode (see Schauffler et al., 1999 for a detailed description). A data set of 73 samples with mixing ratios for three of the five brominated VSLS $\left(\mathrm{CH}_{2} \mathrm{Br}_{2}, \mathrm{CHBr}_{2} \mathrm{Cl}, \mathrm{CHBr}_{3}\right)$ covering the whole track between Japan and Australia was obtained. This data set also will be used in the analysis of typical emission ratios (Sect. 4.2). A detailed presentation of these time series analysed at Miami focusing on a source analysis will be given in a study by K. Krüger (personal communication, 2011).

In May and early June 2008 our group participated in a balloon campaign in Teresina (Brazil), located in the tropics at $5.07^{\circ} \mathrm{S}, 42.87^{\circ} \mathrm{W}$. The balloon carrying the whole air sampler BONBON-I (see Schmidt et al., 1987) was launched on 1 June 2008 by the French Space Agency CNES (Centre National d' Études Spatiales). We collected two samples in the TTL, at altitudes of 14.8 and $17.5 \mathrm{~km}$. The laboratory analyses were conducted in July and August of the same year on the Agilent-7890 GC-MSD and another GC-MSD system (Sichromat 1) using both detector modes EI and NCI for each system. We obtained mixing ratios for the complete spectrum of brominated species, the long-lived and the VSLS.

\subsection{Sample stability}

For the canisters used during List and TransBrom we tested possible concentration drifts of bromocarbons after long periods of storage. These tests indicated stronger exponential declines of the mixing ratios for some of the VSLS, especially $\mathrm{CHBr}_{3}$, when dry air samples were stored. In case of samples with typical tropospheric $\mathrm{H}_{2} \mathrm{O}$ mixing ratios a good stability for all measured compounds was observed over the five month test period.

The storage of dry stratospheric air samples in the canisters of the whole air sampler BONBON-I is also indicated to be problematic for some of the shorter-lived bromocarbons. A repeated measurement of the two TTL samples (using EI mode only) one year after the initial analysis revealed concentration decreases for $\mathrm{CH}_{3} \mathrm{Br}, \mathrm{CH}_{2} \mathrm{Br}_{2}$ and $\mathrm{CHBr}_{3}$, with highest reductions (to about $30 \%$ relative to the initial measurement) for $\mathrm{CHBr}_{3}$. For the temporal stability of $\mathrm{CHBr}_{2} \mathrm{Cl}$ and $\mathrm{CHBrCl}_{2}$ no conclusions could be drawn from this experiment, as the unfavourable EI mode did not allow a peak detection of these species. So, the results of the repeated measurement of the two stratospheric air samples imply that the outcomes from the initial analysis could underestimate the real mixing ratios at the sampling. This issue will be discussed in Sect. 5.1.

\subsection{Scale uncertainties}

For the bromine budget presented in Sect. 5.1 we determined total uncertainties of the analysed mixing ratios. This calculation was done similar to the procedure described by Laube et al. (2008). Statistical errors during the measurements and the systematic error of the calibration scale of the primary standard gas are considered. For the two statistical errors we used the $1 \sigma$ measurement precision of the comparative measurements, for the calibration scale uncertainties the corresponding values specified by the NOAA were applied, which are $3.3 \%$ for halon-1301, $0.2 \%$ for halon- $1211,1.1 \%$ for $\mathrm{CH}_{3} \mathrm{Br}, 6.3 \%$ for $\mathrm{CH}_{2} \mathrm{Br}_{2}$ and $8.3 \%$ for $\mathrm{CHBr}_{3}$. For halon-1202, halon-2402, $\mathrm{CH}_{2} \mathrm{BrCl}, \mathrm{CHBrCl}_{2}$ and $\mathrm{CHBr}_{2} \mathrm{Cl}$ we used a calibration based on comparative measurements of our primary standard gas with a calibration standard at the university of East Anglia (UEA), for which we assumed relatively high systematic errors of 5\% for halon-2402, $10 \%$ for halon-1202 and $20 \%$ for the three polyhalogenated compounds in the overall uncertainty calculations. Possible temporal drifts of the substances in the canisters, as indicated by the experiment described in Sect. 2.2, were not considered in these calculations. An estimate of this potential error is given in Sect. 5.1. 
Table 1. Statistics for the 46 air samples from List, calculated for the analysed brominated VSLS. The variability is defined here as the $1 \sigma$ standard deviation. The measurement precision specifies the $1 \sigma$ standard deviation estimated for the average mixing ratios of the samples.

\begin{tabular}{lcccc}
\hline Substance & \multicolumn{2}{c}{$\begin{array}{c}\text { Mean Mix. Ratio } \\
\text { and Range [ppt] }\end{array}$} & $\begin{array}{c}\text { Variability } \\
\text { [ppt] }\end{array}$ & $\begin{array}{c}\text { Precision } \\
\text { [ppt] }\end{array}$ \\
\hline $\mathrm{CHBr}_{3}$ & 2.02 & $(1.27-5.80)$ & $0.882(43 \%)$ & $0.023(1.1 \%)$ \\
$\mathrm{CH}_{2} \mathrm{Br}_{2}$ & 1.07 & $(0.92-1.55)$ & $0.127(12 \%)$ & $0.020(1.9 \%)$ \\
$\mathrm{CHBr}_{2} \mathrm{Cl}$ & 0.16 & $(0.11-0.28)$ & $0.033(21 \%)$ & $0.011(6.7 \%)$ \\
$\mathrm{CH}_{2} \mathrm{BrCl}$ & $0.10(<0.08-0.15)$ & $0.017(17 \%)$ & $0.020(20 \%)$ \\
\hline
\end{tabular}

\section{Observations source regions}

\subsection{List}

Table 1 shows the statistical summary of the four brominated VSLS measured at Sylt Island. $\mathrm{CHBr}_{3}$ is by far the most abundant of the four gases, with an average of $2.02 \mathrm{ppt}$, while $\mathrm{CH}_{2} \mathrm{Br}_{2}$ exhibits a mean of $1.07 \mathrm{ppt}$. The values for the two species lie on the lower end of the range of means reported for other coastal regions (compare e.g. Zhou et al., 2008; Carpenter et al., 2005). Average and variability of $\mathrm{CHBr}_{3}$ are considerably enhanced by a high-concentration event with two elevated values (up to $5.8 \mathrm{ppt}$ ) on 25 June. The two polyhalogenated show relatively low mixing ratios, especially $\mathrm{CH}_{2} \mathrm{BrCl}$ with an estimated average of only $0.10 \mathrm{ppt}$. Some of the signals of the latter compound are below the detection limit of about 0.08 ppt. For statistical purposes, measurements for $\mathrm{CH}_{2} \mathrm{BrCl}$ that were below detection limit, were assigned a value of $0.07 \mathrm{ppt}$. This mixing ratio is chosen to match the lowest mixing ratios measured during TransBrom, and we think is reasonable considering its relatively long lifetime of 137 days (under average tropospheric conditions, Montzka et al., 2011). The corresponding time series of the four species are shown in Fig. 3. $\mathrm{CH}_{2} \mathrm{Br}_{2}$ (panel A, solid circles, left-hand scale) and $\mathrm{CHBr}_{3}$ (same graph, open circles, right-hand scale) exhibit very similar variance patterns with mixing ratios peaking on 25 June at 03:00 and 06:00 UTC. A qualitatively similar curve is also found for $\mathrm{CHBr} 2 \mathrm{Cl}$ (B, solid circles, left-hand scale), while $\mathrm{CH}_{2} \mathrm{BrCl}$ (same graph, open circles, right-hand scale) - for which we could not obtain results from the first eight canisters due to technical problems - exhibits an independent variability strongly affected by the low measurement precision. The analysis of backward air mass trajectories (shown in Fig. 9) indicate that during the first two days of the time series the air masses passed over the North Sea before arriving at our sampling site (see example for 24 June, panel 1). The highconcentration event on 25 June (panel 2) marks a change in the catchment area from the North Sea to the Baltic Sea. For the following time period until the end of the series the air
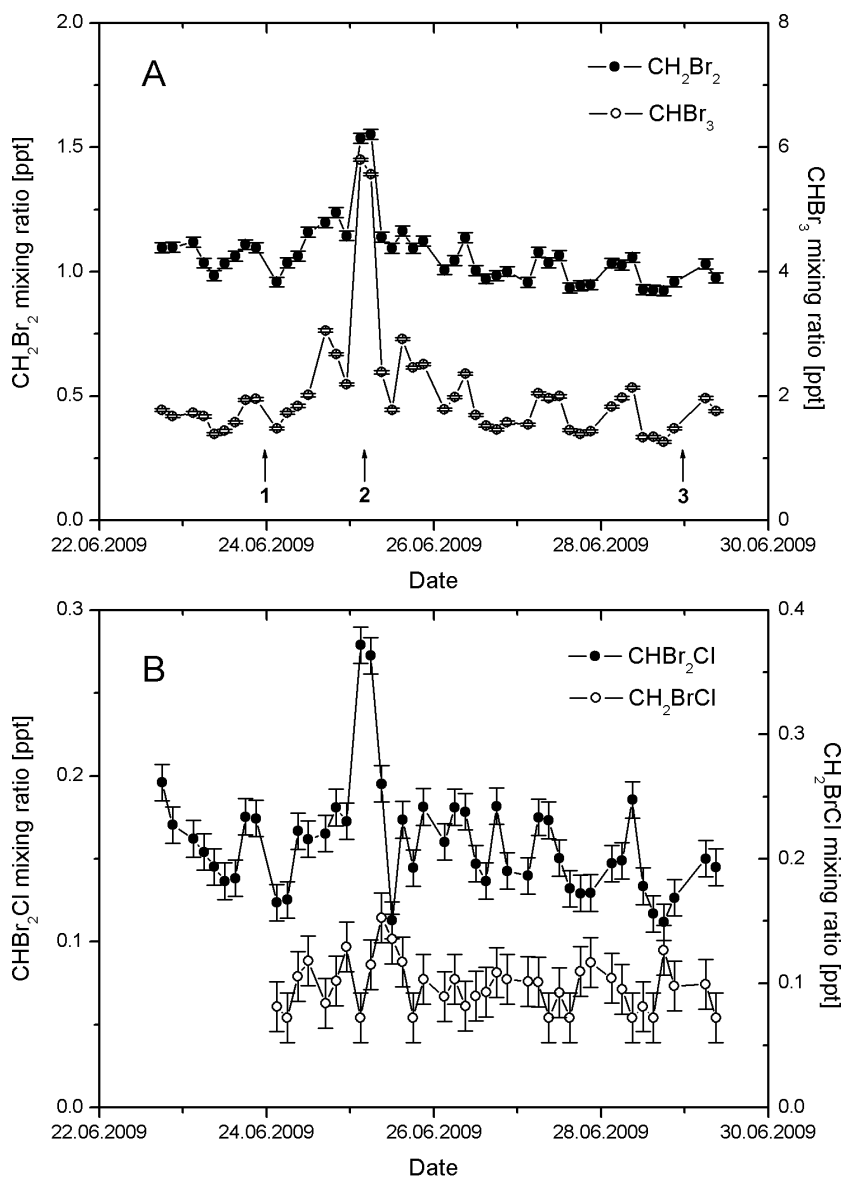

Fig. 3. (A) Time series of $\mathrm{CH}_{2} \mathrm{Br}_{2}$ (solid circles, left-hand scale) and $\mathrm{CHBr}_{3}$ (open circles, right-hand scale) between 22 and 29 June 2009 at List/Sylt. (B) Corresponding results for $\mathrm{CHBr}_{2} \mathrm{Cl}$ (solid circles, left-hand scale) and $\mathrm{CH}_{2} \mathrm{BrCl}$ (open circles, right-hand scale). The error bars give estimates of the $1 \sigma$ measurement precision. The numbers in (A) mark the dates corresponding to the trajectories as labeled in Fig. 9.

masses had been transported over the Baltic Sea in an easterly stream (see example for 29 June, panel 3 ).

The similar levels of short-lived bromocarbons observed for air transported from both the North Sea and the Baltic Sea lead to two important conclusions. First, the mean emission fluxes of these species in the two environments apparently do not differ significantly. Second, we conclude that local sources of brominated VSLS are of minor importance, since local wind directions changing from West (open sea) to East (tidal flats) have no noticeable impact on the observed mixing ratios. This latter finding is also supported by the comparison of local wind speeds and bromocarbon mixing ratios. A correlation between these measures was observed in former studies for regions with strong nearby sources (Zhou et al., 2008), but such correlation is not found for our data from List. The elevated concentrations detected on 25 June suggest that the sampled air masses had crossed extended areas 

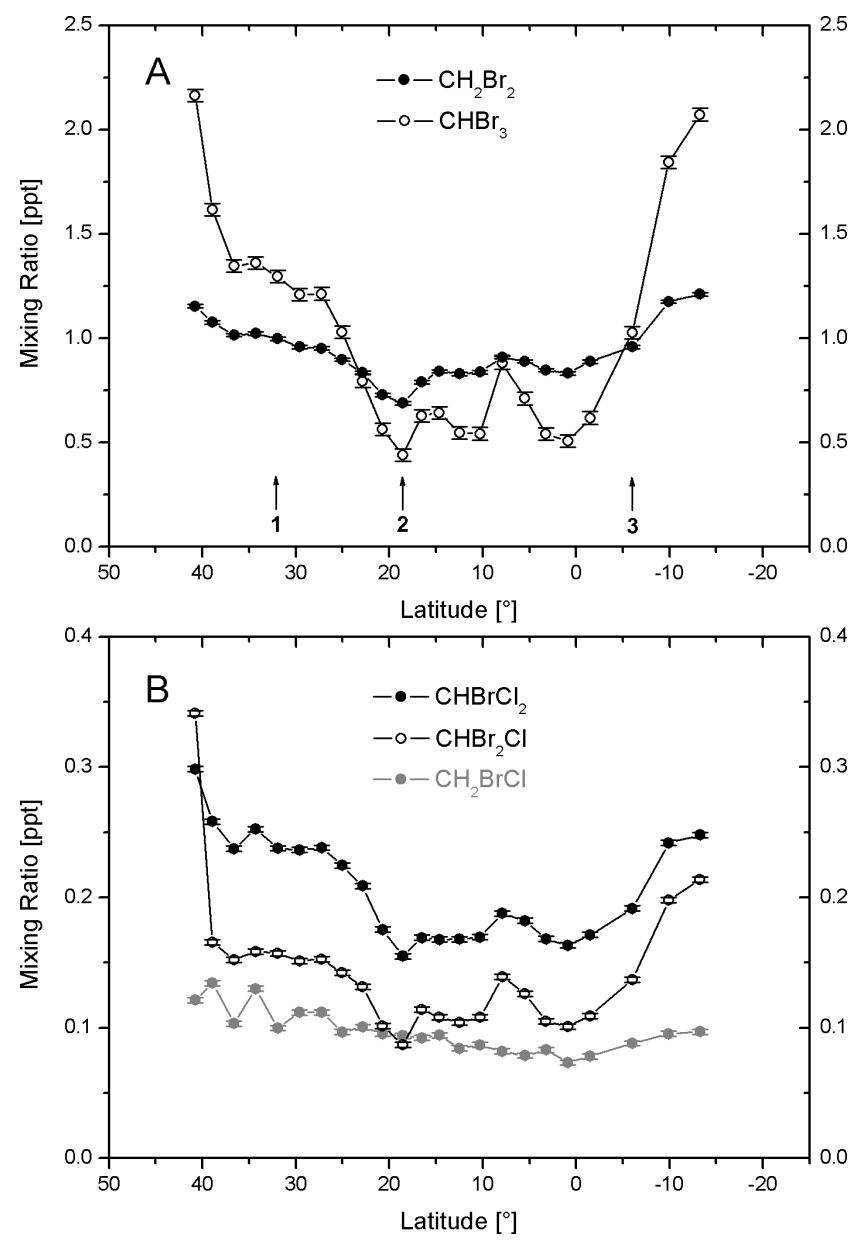

Fig. 4. (A) Mixing ratios of $\mathrm{CH}_{2} \mathrm{Br}_{2}$ (solid circles) and $\mathrm{CHBr}_{3}$ (open circles) as analysed for the 23 IAU TransBrom air samples in the Western Pacific. (B) Corresponding results for $\mathrm{CHBrCl}_{2}$ (solid circles), $\mathrm{CHBr}_{2} \mathrm{Cl}$ (open circles) and $\mathrm{CH}_{2} \mathrm{BrCl}$ (grey symbols). The error bars give the $1 \sigma$ measurement precision. The numbers in panel (A) mark the sites corresponding to the trajectories as labeled in Fig. 10.

of coastal regimes in the transition zone between the North Sea and Baltic Sea (compare panel 2 of Fig. 9). This would be consistent with the importance of bromocarbon emissions in coastal environments.

\subsection{TransBrom}

The time series of the mixing ratios of the five important brominated VSLS for the TransBrom campaign in the West Pacific are illustrated in Fig. 4. $\mathrm{CH}_{2} \mathrm{Br}_{2}$ (panel A, solid circles) and $\mathrm{CHBr}_{3}$ (same panel, open circles) showed relatively low mixing ratios above open ocean areas, around $0.8 \mathrm{ppt}$ for $\mathrm{CH}_{2} \mathrm{Br}_{2}$ and around $0.6 \mathrm{ppt}$ for $\mathrm{CHBr}_{3}$, while higher values of 1.0-1.2 ppt for $\mathrm{CH}_{2} \mathrm{Br}_{2}$ and 1.2-2.1 ppt for $\mathrm{CHBr}_{3}$ were detected near the Japanese coast (at $41^{\circ} \mathrm{N}$ ) and in the vicinity of the islands of Papua New Guinea (at 10 and $13^{\circ} \mathrm{S}$ ).
Table 2. The same as in Table 1 but for the 23 TransBrom IAU air samples from the Western Pacific.

\begin{tabular}{lccc}
\hline Substance & $\begin{array}{c}\text { Mean Mix. Ratio } \\
\text { and Range [ppt] }\end{array}$ & $\begin{array}{c}\text { Variability } \\
\text { [ppt] }\end{array}$ & $\begin{array}{c}\text { Precision } \\
\text { [ppt] }\end{array}$ \\
\hline $\mathrm{CHBr}_{3}$ & $0.91(0.44-2.16)$ & $0.47(51 \%)$ & $0.020(2.2 \%)$ \\
$\mathrm{CH}_{2} \mathrm{Br}_{2}$ & $0.92(0.69-1.21)$ & $0.13(15 \%)$ & $0.006(0.6 \%)$ \\
$\mathrm{CHBrCl}_{2}$ & $0.20(0.16-0.30)$ & $0.04(19 \%)$ & $0.002(0.9 \%)$ \\
$\mathrm{CHBr}_{2} \mathrm{Cl}$ & $0.14(0.09-0.34)$ & $0.04(31 \%)$ & $0.002(1.2 \%)$ \\
$\mathrm{CH}_{2} \mathrm{BrCl}$ & $0.10(0.07-0.13)$ & $0.02(16 \%)$ & $0.002(2.2 \%)$ \\
\hline
\end{tabular}

These observations are consistent with a strong influence from coastal sources and relatively weak emissions in open ocean areas. The corresponding backward trajectories, displayed in Fig. 10, confirm a slowly decreasing coastal influence at the beginning of the cruise, as the winds persistently transported air masses from the North (see example in panel 1 for $32^{\circ} \mathrm{N}$ ). Between 0 and $20^{\circ} \mathrm{N}$ typically easterly to northerly winds advected air from open ocean regions, as shown on panel 2. For the air samples collected between 6 and $13^{\circ} \mathrm{S}$ (panel 3, $6^{\circ} \mathrm{S}$ ) air masses arrived from the Southeast after passing through a region with larger islands in the Solomon Sea. The observation of relatively low concentrations above most of the open ocean regions is in agreement with other studies (e.g. Quack and Wallace, 2004; Yokouchi et al., 2005). Considerably elevated mixing ratios, as reported by Atlas et al. (1993) for upwelling regions in the equatorial Eastern Pacific, were not observed during this cruise. This is consistent with an absence of such upwelling zones associated with high biogenic activity in the Western Pacific. Similar profiles, with elevated values near the coastlines, were found for $\mathrm{CHBrCl}_{2}$ (Fig. 4, panel B, solid black circles) and $\mathrm{CHBr}_{2} \mathrm{Cl}$ (same panel, open circles). In agreement with our observations at List, $\mathrm{CH}_{2} \mathrm{BrCl}$ (same panel, grey circles) showed a mixing ratio time series that was not correlated to the other bromocarbon compounds.

A comparison with the air samples analysed at the University of Miami (UM, not shown in the graphs) reveals in total good agreement with the IAU measurements, especially for $\mathrm{CHBr}_{3}$ and $\mathrm{CHBr}_{2} \mathrm{Cl}$. A difference between the data is apparent for the $\mathrm{CH}_{2} \mathrm{Br}_{2}$, with around $20 \%$ higher values for the UM data set, while the patterns of variation match very well. In agreement with the findings from the IAU data, the higher spatial resolution of the UM samples also does not reveal any high-concentration events above the open ocean. The elevated mixing ratios which were observed during the beginning and the end of the cruise, but which are not covered by the IAU data, will be discussed in a study by K. Krüger (personal communication, 2011).

In Table 2 a summary for the data sets from the IAU Frankfurt is shown. Due to the uneven distributions of sources and sinks along the track in the West Pacific the mixing ratio data tend to be better described by a log-normal rather than 
a normal distribution. Thus, the geometric values of mean and standard deviation were calculated for the overall summary of this data set. (The differences between geometric and arithmetic means are very small, only for $\mathrm{CHBr}_{3}$ a significantly higher arithmetic mean $(+13 \%)$ was determined.) For the subset of open ocean samples discussed below, arithmetic means are given, as these have proven to be more appropriate for this case. $\mathrm{CHBr}_{3}$ shows an overall mean mixing ratio of $0.91 \mathrm{ppt}$, with a range between 0.44 and $2.16 \mathrm{ppt}$. As noted above, the higher values were detected for samples with coastal influence, while the open ocean mixing ratios were considerably lower. When excluding all samples with trajectories passing through regions with larger islands, we find an average of only $0.62 \mathrm{ppt}$ for $\mathrm{CHBr}_{3}$. Considering the whole data set, $\mathrm{CH}_{2} \mathrm{Br}_{2}$ exhibits an average of $0.92 \mathrm{ppt}$ and a range between 0.69 and 1.21 ppt. For the limited set of samples without coastal influence we obtain an average of $0.83 \mathrm{ppt}$ for this substance. Thus, above the open ocean $\mathrm{CH}_{2} \mathrm{Br}_{2}$ had somewhat higher concentrations than $\mathrm{CHBr}_{3}$, which can be explained by the combination of its relatively longer lifetime and the absence of significant emissions. The three polyhalogenated compounds show average mixing ratios of $0.10,0.20$ and $0.14 \mathrm{ppt}$ (for $\mathrm{CH}_{2} \mathrm{BrCl}, \mathrm{CHBrCl}_{2}$ and $\mathrm{CHBr}_{2} \mathrm{Cl}$, respectively). The corresponding open ocean values of $0.09,0.17$ and $0.11 \mathrm{ppt}$ (in the above order) are also lower compared to those with coastal influence.

\section{Regression analyses}

In the following sections we present different regression analyses carried out to investigate possible relationships between the mixing ratios of brominated VSLS. Several previous studies reported linear relationships between the mixing ratios of $\mathrm{CHBr}_{3}, \mathrm{CH}_{2} \mathrm{Br}_{2}$ and $\mathrm{CHBr}_{2} \mathrm{Cl}$ (e.g. O'Brien et al., 2009; Yokouchi et al., 2005), indicating that these substances share the same sources. Li et al. (1994) suggested the additional possibility that reactions of $\mathrm{CHBr}_{3}$ with seawater chlorine could produce $\mathrm{CHBr}_{2} \mathrm{Cl}$ and thus account for the observed correlations to this compound.

\subsection{Linear regression}

Using the orthogonal distance regression (ODR) - which considers the distances in $\mathrm{x}$ - and $\mathrm{y}$-direction rather than only the deviations on the y-axis - we calculated linear fits and the related coefficients of determination for the different species with respect to $\mathrm{CHBr}_{3}$. Figure 5 displays the results for $\mathrm{CH}_{2} \mathrm{Br}_{2}$ and $\mathrm{CHBr}_{2} \mathrm{Cl}$ as analysed for the List data. As in previous studies, the three compounds exhibit good correlations, with coefficients of determination of 0.89 and 0.73 for $\mathrm{CH}_{2} \mathrm{Br}_{2}$ versus $\mathrm{CHBr}_{3}$ and $\mathrm{CHBr}_{2} \mathrm{Cl}$ versus $\mathrm{CHBr}_{3}$, respectively. The corresponding plot for the TransBrom IAU data, shown in Fig. 6 (panel A), also demonstrates strong linear relationships for the three compounds. The coefficients of

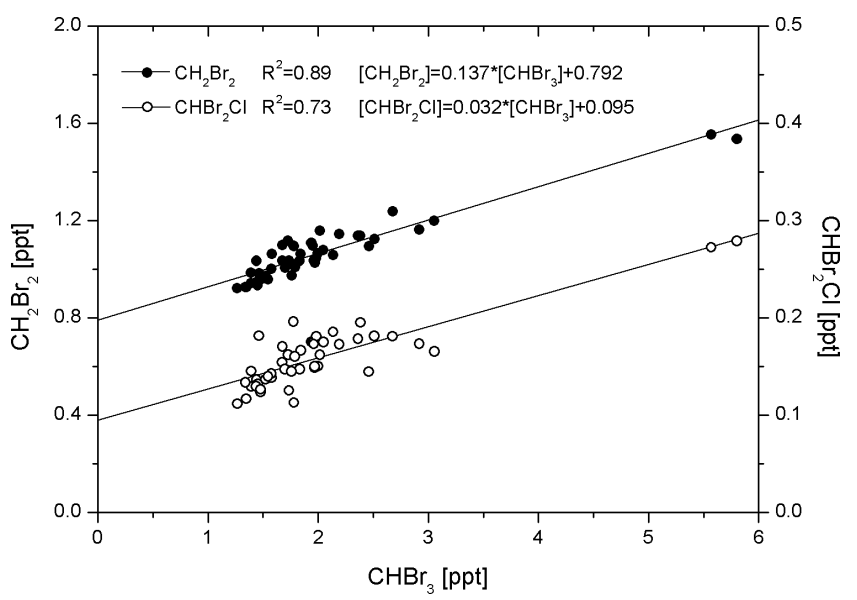

Fig. 5. Linear orthogonal regressions of $\mathrm{CH}_{2} \mathrm{Br}_{2}$ and $\mathrm{CHBr}_{2} \mathrm{Cl}$ each versus $\mathrm{CHBr}_{3}$ for the List dataset. Added are the corresponding determination coefficients $R^{2}$ and the regression equations.

determination reach very high values of 0.91 and 0.97 for the two correlations. One outlying data point for $\mathrm{CHBr}_{2} \mathrm{Cl}$ (encircled in the graph) was excluded from the calculations. It is apparent that for some of the samples with coastal influence (visible especially in the UM data set, see analysis and discussion in Sect. 4.2.2) the $\mathrm{CHBr}_{2} \mathrm{Cl}$ mixing ratios show an increase that does not match the changes of $\mathrm{CH}_{2} \mathrm{Br}_{2}$ and $\mathrm{CHBr}_{3}$, considering its atmospheric lifetime lying between the two other species. This could be an indication for additional $\mathrm{CHBr}_{2} \mathrm{Cl}$ emissions from an independent source.

The lower graph B in Fig. 6 shows the linear regression for $\mathrm{CHBrCl}_{2}$ and $\mathrm{CH}_{2} \mathrm{BrCl}$, both versus $\mathrm{CHBr}_{3}$ again, as analysed for the TransBrom IAU data. We find a high correlation of $\mathrm{CHBrCl}_{2}$ to $\mathrm{CHBr}_{3}$ (with $R^{2}=0.87$ ), while for $\mathrm{CH}_{2} \mathrm{BrCl}$ only a weak relationship to $\mathrm{CHBr}_{3}$ is indicated $\left(R^{2}=0.42\right)$. A study in the Arctic boundary layer at Alert (CAN) also revealed a significant correlation of $\mathrm{CHBrCl}_{2}$ to $\mathrm{CHBr}_{3}$ and $\mathrm{CHBr}_{2} \mathrm{Cl}$ (Li et al., 1994). Corresponding analyses of the $\mathrm{UM}$ data sets for $\mathrm{CHBr}_{3}, \mathrm{CH}_{2} \mathrm{Br}_{2}$ and $\mathrm{CHBr}_{2} \mathrm{Cl}$ confirm the above findings of a strong linear relationship between the three species. The results of these calculations and the regression analyses of the two other data sets discussed above are listed in Tables 3, 4 and 5.

Summarising the results of the linear regression analyses, it can be noted that for four of the five brominated VSLS $\left(\mathrm{CH}_{2} \mathrm{Br}_{2}, \mathrm{CHBr}_{3}, \mathrm{CHBr}_{2} \mathrm{Cl}\right.$ and $\left.\mathrm{CHBrCl}_{2}\right)$ significant linear relationships are found. Very few of the samples collected during TransBrom suggest additional independent emissions for $\mathrm{CHBr}_{2} \mathrm{Cl}$, while for $\mathrm{CH}_{2} \mathrm{BrCl}$ independent sources are indicated by both data sets. The presence of high correlations implies that the related species are emitted from the same sources or source regions in relatively consistent and constant ratios. The determination of these emission ratios could help to predict the distributions of the related species, if the atmospheric levels of one substance are well characterised. 


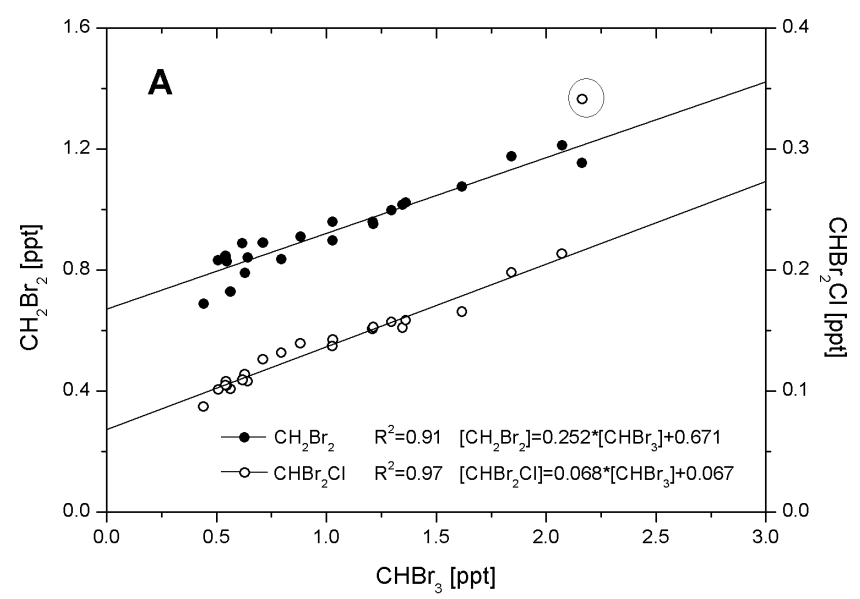

Table 4. As in Table 3 but for the IAU TransBrom dataset. For $\mathrm{CHBr}_{2} \mathrm{Cl}$ one outlying data point was excluded from the analysis.

\begin{tabular}{|c|c|c|c|c|c|c|}
\hline \multirow[t]{3}{*}{ Substance } & \multicolumn{6}{|c|}{ Linear Regression: $[Y]=m \cdot[X]+b$} \\
\hline & \multicolumn{3}{|c|}{$X=\mathrm{CH}_{2} \mathrm{Br}_{2}$} & \multicolumn{3}{|c|}{$X=\mathrm{CHBr}_{3}$} \\
\hline & $m$ & $b$ & $R^{2}$ & $m$ & $b$ & $R^{2}$ \\
\hline $\mathrm{CHBr}_{3}$ & 4.0 & -2.7 & 0.91 & & & \\
\hline $\mathrm{CH}_{2} \mathrm{Br}_{2}$ & & & & 0.25 & 0.67 & 0.91 \\
\hline $\mathrm{CHBr}_{2} \mathrm{Cl}$ & 0.24 & -0.09 & 0.91 & 0.07 & 0.07 & 0.97 \\
\hline $\mathrm{CHBrCl}_{2}$ & 0.26 & -0.03 & 0.73 & 0.07 & 0.13 & 0.87 \\
\hline $\mathrm{CH}_{2} \mathrm{BrCl}$ & 0.06 & 0.04 & 0.25 & 0.02 & 0.08 & 0.42 \\
\hline
\end{tabular}

Table 5. As in Table 3 but for the UM TransBrom dataset.

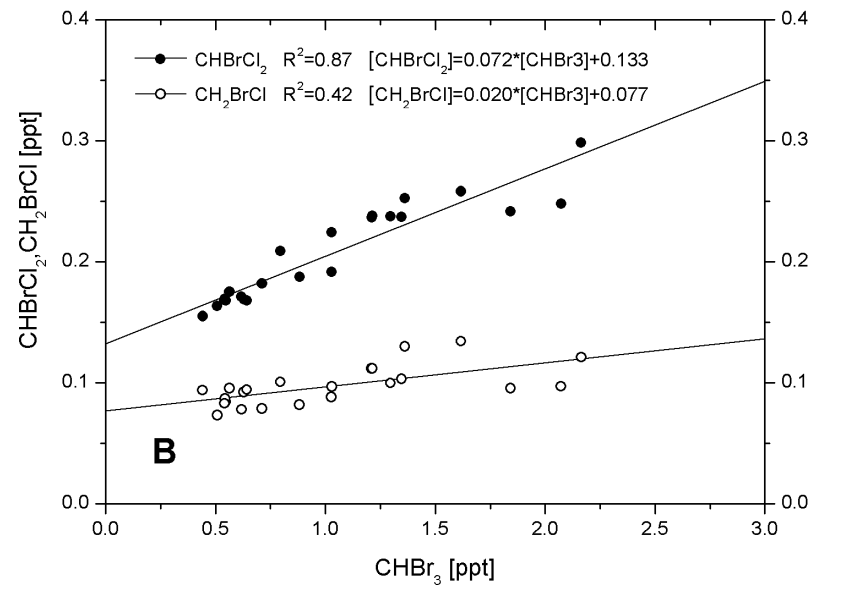

\begin{tabular}{|c|c|c|c|c|c|c|}
\hline \multirow[t]{3}{*}{ Substance } & \multicolumn{6}{|c|}{ Linear Regression: $[Y]=m \cdot[X]+b$} \\
\hline & \multicolumn{3}{|c|}{$X=\mathrm{CH}_{2} \mathrm{Br}_{2}$} & \multicolumn{3}{|c|}{$X=\mathrm{CHBr}_{3}$} \\
\hline & $m$ & $b$ & $R^{2}$ & $m$ & $b$ & $R^{2}$ \\
\hline $\mathrm{CHBr}_{3}$ & 3.4 & -2.9 & 0.86 & & & \\
\hline $\mathrm{CH}_{2} \mathrm{Br}_{2}$ & & & & 0.29 & 0.84 & 0.86 \\
\hline $\mathrm{CHBr}_{2} \mathrm{Cl}$ & 0.36 & -0.24 & 0.60 & 0.11 & 0.06 & 0.65 \\
\hline
\end{tabular}

It should be pointed out that during the initial emission from the algae species into the ocean water deviating abundance ratios are expected, due to different rates of degradation in the surface water prior to the emission through the sea surface. This however is not of relevance to our study as we only consider emissions into the atmosphere and make no assumptions or conclusions about the initial emissions from the biological processes.

\subsection{Emission ratios}

\subsubsection{Theoretical considerations}

An intuitive approach to deriving typical emission ratios from the data of compounds with similar sources is the use of correlation plots of compound ratios versus compound concentration, for example, $\left[\mathrm{CH}_{2} \mathrm{Br}_{2}\right] /\left[\mathrm{CHBr}_{3}\right]$ versus $\left[\mathrm{CHBr}_{3}\right]$. For this example we expect an increase of the ratio $\left[\mathrm{CH}_{2} \mathrm{Br}_{2}\right] /\left[\mathrm{CHBr}_{3}\right]$ for decreasing $\mathrm{CHBr}_{3}$ concentrations, due to the following reasons: A stronger mixing with background air always tends to enhance the $\left[\mathrm{CH}_{2} \mathrm{Br}_{2}\right] /\left[\mathrm{CHBr}_{3}\right]$ ratio, as the photochemically aged background air exhibits relatively lower concentrations of the shorter-lived compound $\mathrm{CHBr}_{3}$. In addition, the stronger degradation of $\mathrm{CHBr}_{3}$ relative to $\mathrm{CH}_{2} \mathrm{Br}_{2}$ (especially by photolysis) also directly enhances this ratio when longer transport times occur. The smallest measured ratio in such a graph should give an estimate of the emission ratio, since these data reflect samples with minimal impact from mixing and decomposition. 


\section{Three-component analyses}

For a similar analysis of three well correlated compounds with assumed constant emission ratios a plot of, for example, $\left[\mathrm{CHBr}_{3}\right] /\left[\mathrm{CH}_{2} \mathrm{Br}_{2}\right]$ versus $\left[\mathrm{CHBr}_{2} \mathrm{Cl}\right] /\left[\mathrm{CH}_{2} \mathrm{Br}_{2}\right]$ can be produced. Following McKeen and Liu (1993) a "dilution line" and a "chemical decay line", both departing from the point of the initial ratios at the time of the emission, should enclose the scattered data. The dilution line illustrates the relationship between the data for the case that the considered air parcels are mixed with background air, without chemical decay processes taking place. The temporal change in the concentration of species $X$ due to dilution is then determined by the mixing coefficient $c$, its concentration $[X]$ and its background concentration $[X]_{\mathrm{b}}$ :

$\frac{d[X]}{d t}=-c \cdot\left([X]-[X]_{\mathrm{b}}\right)$

Under the assumption of relatively small background concentrations of the two shorter-lived species $\left([X] \gg[X]_{\mathrm{b}}\right.$ and $[Y] \gg[Y]_{\mathrm{b}}$ ), in our case $\mathrm{CHBr}_{3}$ and $\mathrm{CHBr}_{2} \mathrm{Cl}$, and a constant mixing coefficient $c$, the dilution or relative concentration change $\Delta[X] /[X]$ after a given time interval $\Delta t$ will be equal for the two shorter-lived substances. Thus the resulting dilution line (for $[X] /[Z]$ versus $[Y] /[Z]$ ) has a slope of 1 on a double-logarithmic scale.

The chemical decay line describes the relationship between the concentrations of the three compounds when changes in $[X],[Y]$ and $[Z]$ are exclusively governed by chemical decomposition by a pseudo-first-order chemical reaction with the loss rates $L_{X}, L_{Y}$ and $L_{Z}$ :

$\frac{d[X]}{d t}=-L_{X} \cdot[X]$

The loss rates are determined by the $\mathrm{OH}$ reaction rate coefficient, the $\mathrm{OH}$ concentration and the photolysis rate. By replacing the loss rates of the considered compounds with the reciprocal of their local lifetimes $1 / \tau$ and solving the differential equations for the concentrations of the three species $X$, $Y, Z$, a linear relationship can be derived for $[Y] /[Z]$ versus $[X] /[Z]$ on a log-log scale representing the chemical decay line. The associated slope $m$ is determined by the three lifetimes (Roberts et al., 1984; Parrish et al., 1992; McKeen and Liu, 1993):

$m=\frac{1 / \tau_{y}-1 / \tau_{z}}{1 / \tau_{x}-1 / \tau_{z}}$

McKeen and Liu (1993) have used a mesoscale model to predict the concentrations of three hydrocarbons with different lifetimes and emission rates in specific ratios. They show that under realistic conditions essentially all observed ratios between the three species are expected to lie between the two lines, even if one of the two processes, chemical decay or dilution with background air, is excluded completely. This is due to processes ignored in the derivation of these lines, i.e. mixing processes with non-background air and mixing of two parcels characterised by different photochemical ages.

\section{Two-component analyses}

Several studies (Carpenter et al., 2003; Zhou et al., 2008) directly used the linear correlation analysis between the mixing ratios of e.g. $\mathrm{CH}_{2} \mathrm{Br}_{2}$ and $\mathrm{CHBr}_{3}$ to calculate emission ratios. It can be shown that under certain conditions the slope of such a regression line is a good estimate for the initial concentration ratio. In case of a pure dilution - an approximation valid for measurements in close proximity to the sources - the initial concentration of substance $X$, denoted as $[X]_{0}$, decreases due to mixing with ambient air that exhibits a certain background concentration $[X]_{\mathrm{b}}$ as described by Eq. (1). This equation can be transformed and integrated to obtain an exponential expression for the temporal change of the concentrations $[X]$ and $[Y]$. Assuming again a constant mixing coefficient $c$ (being equal for both compounds), the exponential term can be eliminated to obtain an equation for $[Y]$ depending on $[X]$.

$[Y]=\frac{[Y]_{0}-[Y]_{\mathrm{b}}}{[X]_{0}-[X]_{\mathrm{b}}} \cdot[X]+[Y]_{\mathrm{b}}-[X]_{\mathrm{b}} \cdot \frac{[Y]_{0}-[Y]_{\mathrm{b}}}{[X]_{0}-[X]_{\mathrm{b}}}$

It can be seen that the slope of this linear relationship will be equal to the initial concentration ratio $[Y]_{0} /[X]_{0}$ (thus to the relative emission rates) if the background concentrations of the two substances $[X]_{\mathrm{b}}$ and $[Y]_{\mathrm{b}}$ are small compared to $[X]_{0}$ and $[Y]_{0}$ or if their ratios to the initial concentrations are approximately equal $\left([X]_{\mathrm{b}} /[X]_{0} \simeq[Y]_{\mathrm{b}} /[Y]_{0}\right)$, as expected for the case of similar lifetimes. In the general case of significant background concentrations and differing lifetimes, as for e.g. $\mathrm{CH}_{2} \mathrm{Br}_{2}$ versus $\mathrm{CHBr}_{3}$, the slope of the regression line will deviate from the initial concentration ratio.

The opposite scenario of measurements taken at a larger distance from the regions of emission may be treated with a pure chemical decay according to a pseudo first-order process, as given in Eq. (2). Similarly to the steps above, the differential equations can be solved for the two species $X$ and $Y$, and the exponential time factor is eliminated to obtain the following two equivalent expressions:

$$
\begin{aligned}
& \ln \frac{[Y]}{[X]}=\left(\frac{\tau_{x}}{\tau_{y}}-1\right) \ln [X]+\left(\ln [Y]_{0}-\frac{\tau_{x}}{\tau_{y}} \ln [X]_{0}\right) \\
& {[Y]=\frac{[Y]_{0}}{[X]_{0}^{\frac{\tau_{x}}{\tau_{y}}}} \cdot[X]^{\frac{\tau_{x}}{\tau_{y}}}}
\end{aligned}
$$

Thus, for a plot of the natural logarithm of the ratio $[Y] /[X]$ versus the natural logarithm of $[X]$ the slope of the corresponding regression line is determined by the lifetimes $\tau_{x}$ and $\tau_{y}$. The relationship $[Y]([X])$ is generally nonlinear, with a shape depending on the initial concentration ratio, the ratio of the lifetimes and the concentration $[X]$. An analysis of Eq. (6) shows that the slope from a linear regression can deviate positively (in case of photochemically young air samples) or negatively (in case of considerably aged air) from the real ratio of e.g. $\left[\mathrm{CHBr}_{3}\right]_{0} /\left[\mathrm{CH}_{2} \mathrm{Br}_{2}\right]_{0}$. If the lifetimes 


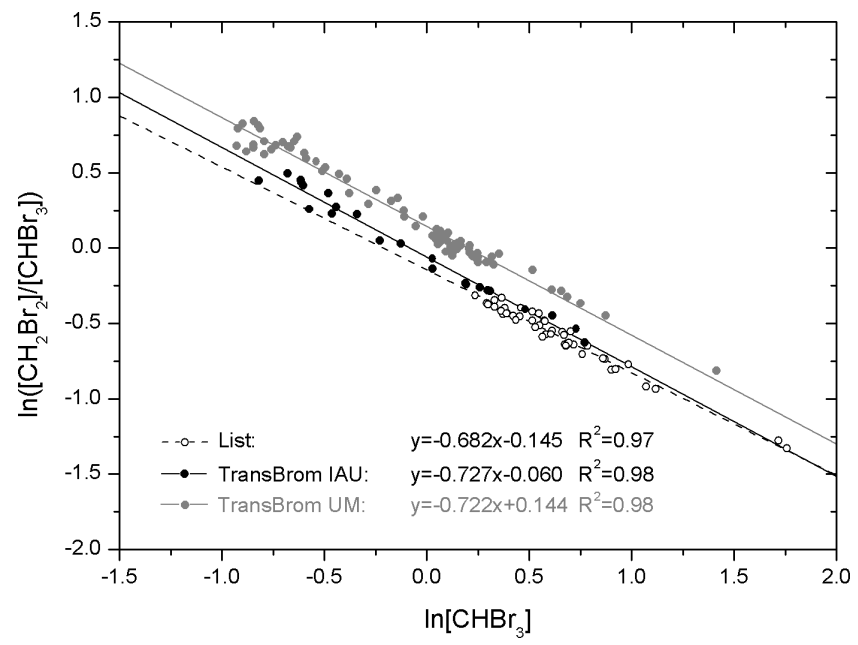

Fig. 7. Linear orthogonal regressions of the natural logarithm of the ratio $\left[\mathrm{CH}_{2} \mathrm{Br}_{2}\right]$ to $\left[\mathrm{CHBr}_{3}\right]$ versus $\ln \left[\mathrm{CHBr}_{3}\right]$ for the three datasets (see labels and description in the text). The corresponding determination coefficients $R^{2}$ and the regression equations are listed in the graph.

of the two considered species are similar, Eq. (6) will reduce to a nearly linear curve of the same form as is valid for a dilution with the constraints of zero background concentrations. Thus, a corresponding analysis of $\left[\mathrm{CHBr}_{2} \mathrm{Cl}\right]$ versus $\left[\mathrm{CH}_{2} \mathrm{Br}_{2}\right]$ or $\left[\mathrm{CHBr}_{3}\right]$ is less sensitive (compared to $\left[\mathrm{CH}_{2} \mathrm{Br}_{2}\right]$ versus $\left.\left[\mathrm{CHBr}_{3}\right]\right)$ to the photochemical age of the considered air masses, and the slope of the regression line yields a relatively stable estimate of the emission ratio. The same conclusions can be drawn for the scenario of a pure dilution: a mixing under consideration of realistic background values leads to relatively smaller deviations in the slope from the case with zero background if the lifetime differences are also relatively smaller.

\subsubsection{Analyses and discussion}

\section{Two-component analyses}

The linear regression for the List dataset yields a slope of 0.14 for $\mathrm{CH}_{2} \mathrm{Br}_{2}$ versus $\mathrm{CHBr}_{3}$. This value is in good agreement with other published data from coastal mid-latitude sites, as the 0.15 determined for measurements at Mace Head (Carpenter et al., 2003) and 0.14 derived from measurements in the seacoast region of New Hampshire (Zhou et al., 2008). The results for the TransBrom IAU data indicate a higher slope of 0.25 for the two species, which can be explained by a stronger impact of chemical decay on the concentration ratios.

Following Carpenter et al. (2003) a correlation according to Eq. (5) was investigated to evaluate the impact from degradation processes. The results of these analyses for $\mathrm{CH}_{2} \mathrm{Br}_{2}$ and $\mathrm{CHBr}_{3}$, the two species with a relatively large lifetime difference, are displayed in Fig. 7. The correlations for the three datasets (List, TransBrom IAU, TransBrom UM) are very strong, with determination coefficients between 0.97 and 0.98. According to Eq. (5) the slopes correspond to lifetime ratios $\tau_{\mathrm{CHBr}_{3}} / \tau_{\mathrm{CH}_{2} \mathrm{Br}_{2}}$ of $0.32,0.27$ and 0.28 for List, TransBrom IAU and TransBrom UM, respectively. The lifetime values published by Hossaini et al. (2010) $\left(\mathrm{CHBr}_{3}: 16\right.$ days, $\mathrm{CH}_{2} \mathrm{Br}_{2}$ : 52 days, for the near-surface tropics) and Montzka et al. (2011) $\left(\mathrm{CHBr}_{3}\right.$ : 24 days, $\mathrm{CH}_{2} \mathrm{Br}_{2}: 123$ days, for average tropospheric conditions) would correspond to lifetime ratios of 0.31 and 0.20 , respectively. Our findings agree very well with these bounds, which is, in combination with the strength of the correlations, a good indication that degradation processes had a strong impact on the analysed distributions of the brominated compounds in List and above the Western Pacific. This implies that the relationship between $\left[\mathrm{CH}_{2} \mathrm{Br}_{2}\right]$ and $\left[\mathrm{CHBr}_{3}\right]$ is expected to follow a non-linear function according to Eq. (6) so that the slope of the corresponding regression line would alter with the photochemical age of the considered air parcels.

Regarding the results for $\mathrm{CHBr}_{2} \mathrm{Cl}$, we obtain very similar slopes of 0.23 and 0.24 (versus $\mathrm{CH}_{2} \mathrm{Br}_{2}$, see Tables 3 and 4) for List and TransBrom IAU. As discussed in the previous section, the possible deviations of the slope values from the emission ratio are relatively smaller compared to the findings for $\mathrm{CH}_{2} \mathrm{Br}_{2}$ versus $\mathrm{CHBr}_{3}$, since the lifetime ratio of $\mathrm{CHBr}_{2} \mathrm{Cl}$ to $\mathrm{CH}_{2} \mathrm{Br}_{2}$ is closer to 1 (about 0.6, lifetime estimates of $\mathrm{CHBr}_{2} \mathrm{Cl}$ discussed below). Thus, the derived slopes should yield good estimates for the corresponding emission ratios. For $\mathrm{CHBrCl}_{2}$, analysed only for the TransBrom data, an emission ratio of 0.26 to $\mathrm{CH}_{2} \mathrm{Br}_{2}$ (see Table 4) can be derived from the regression analysis.

\section{Three-component analyses}

In the following section we use the approach of McKeen and Liu (1993), explained above, to derive estimates for the emission ratios of $\mathrm{CHBr}_{3} / \mathrm{CH}_{2} \mathrm{Br}_{2} / \mathrm{CHBr}_{2} \mathrm{Cl}$. Using Eq. (3) (with $X=\mathrm{CHBr}_{2} \mathrm{Cl}, Y=\mathrm{CHBr}_{3}, Z=\mathrm{CH}_{2} \mathrm{Br}_{2}$ ) and applying local lifetimes of 26, 69 and 120 days for $\mathrm{CHBr}_{3}, \mathrm{CHBr}_{2} \mathrm{Cl}$ and $\mathrm{CH}_{2} \mathrm{Br}_{2}$ (Ko et al., 2003; Yokouchi et al., 2005; O'Brien et al., 2009) the slope for the chemical decay line on a doublelogarithmic scale is calculated to be 4.89. As noted above, we expect a slope of 1 for a dilution line based on the assumption of pure dilution processes. To estimate emission ratios from a broad database containing samples of a range of characteristics (in terms of dilution and chemical decay processes), we combined the data sets from the two source regions under the assumption of (1) similar relative emission strengths and (2) similar lifetime ratios in both regions. (1) Is supported by the above findings of the two-component analyses. (2) Is also justified, given that only the ratios of the lifetimes must be similar. Hossaini et al. (2010) found altitude dependent ratios of the local tropical lifetimes for $\mathrm{CHBr}_{3}$ and $\mathrm{CH}_{2} \mathrm{Br}_{2}$ ranging from 0.31 (16/52 days) near the 


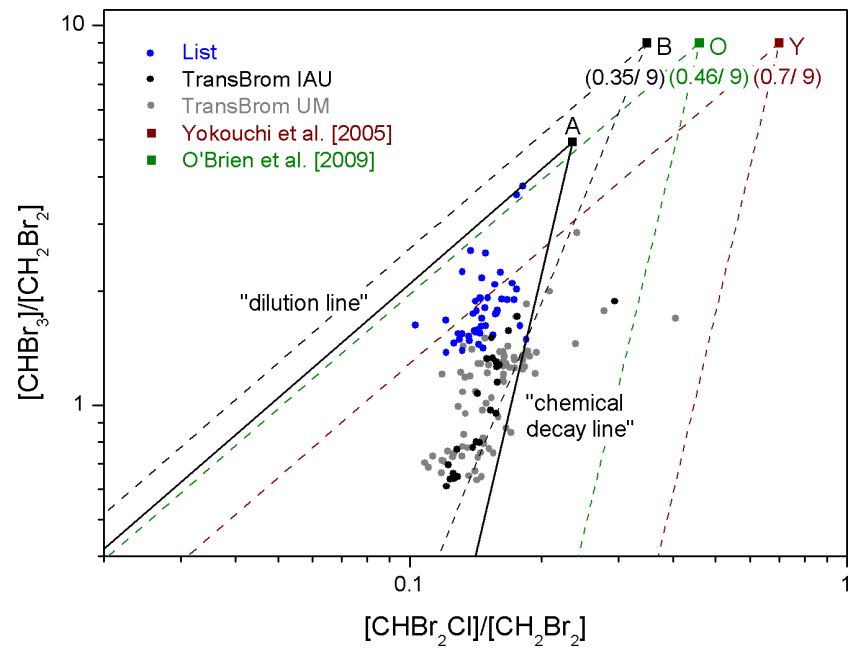

Fig. 8. Ratios of $\left[\mathrm{CHBr}_{3}\right] /\left[\mathrm{CH}_{2} \mathrm{Br}_{2}\right]$ versus the ratios of $\left[\mathrm{CHBr}_{2} \mathrm{Cl}\right] /\left[\mathrm{CH}_{2} \mathrm{Br}_{2}\right]$ for the the three datasets List (blue), TransBrom IAU (black) and TransBrom UM (grey). Following an approach of McKeen and Liu (1993), the data points are expected to be enclosed by a "dilution line" and a "chemical decay line" (whose slopes are derived from theoretical considerations), both departing from the point with the initial ratios during the emission. The brown and green lines illustrate corresponding outcomes from Yokouchi et al. (2005) and O' Brien et al. (2009). See text for further descriptions.

surface to 0.09 (21/237 days) in the upper troposphere (500$200 \mathrm{hPa}$ region). For the lower troposphere (1000-500 hPa) Hossaini et al. (2010) report a ratio of 0.26 (17/65 days). This compares rather well with the ratio of local lifetimes of 0.22 (26/120 days) given by Ko et al. (2003) for average tropospheric conditions at about $500 \mathrm{hPa}$ altitude. This shows that the lifetime ratios vary mainly with altitude and less with latitude. As all our observations are in the marine boundary layer, we expect that they have experienced similar lifetime ratios during their transport history from the sources to the place of observation, which is the prerequisite for using Eq. (3).

The corresponding plot for the three data sets is shown in Fig. 8. With the constraints for the dilution line to intersect at the upper left and the chemical decay line to intersect at the lower right portion of the data points, so that all values are enclosed by the two lines, we construct the intersection of the two lines based on the data sets List + TransBrom IAU (blue and black symbols) in point $\mathrm{A}$, which yields the following lower estimate for the emission ratios of the three considered compounds: 0.24 and 4.9 for $\mathrm{CHBr}_{2} \mathrm{Cl}$ and $\mathrm{CHBr}_{3}$, both relative to $\mathrm{CH}_{2} \mathrm{Br}_{2}$.

Due to significant scale differences between the IAU and the UM data we standardised the data from Miami before adding them to the plot by applying a linear regression for the 23 air samples collected nearly at the same time (with time lags of about $5 \mathrm{~min}$ ). The correlations between the two data sets (see Fig. 11) are very strong, with determination coefficients of $0.98,0.95$ and 0.92 for $\mathrm{CHBr}_{3}, \mathrm{CH}_{2} \mathrm{Br}_{2}$ and $\mathrm{CHBr}_{2} \mathrm{Cl}$, which justifies the use of this approach. The TransBrom UM data treated in this way (displayed in grey) are generally consistent with the corresponding IAU data and the position derived for the two lines. A relatively lower measurement precision, especially for the $\mathrm{CHBr}_{2} \mathrm{Cl}$ measurements at Miami, accounts for the larger scatter of these data. Nevertheless, as already indicated by the linear regression analysis above, several points (identical with some of the coastal values discussed in Sect. 4.1) clearly fall outside the area spanned by the two lines derived from the two other data sets, because of unexpectedly high $\mathrm{CHBr}_{2} \mathrm{Cl}$ mixing ratios. We ignore these values when determining the dilution line, assuming that the outliers are a result of additional independent sources for this compound.

Many of the West Pacific data points lie close to the chemical decay line, which is consistent with the observation of very low mixing ratios above the open ocean caused by intense decomposition during long transport times. The List data exhibit a larger variation, with at least two points (identical with the mixing ratio maxima for $\mathrm{CHBr}_{3}$ and $\mathrm{CH}_{2} \mathrm{Br}_{2}$ ) suggesting a significant impact from dilution processes. But as indicated by the findings in Fig. 7 most of the List data also emphasize the influence of degradation processes rather than of a pure mixing with background air. So, a realistic position of the dilution line is likely to be somewhat higher than drawn, as would be the initial concentration ratios.

The findings of Yokouchi et al. (2005), drawn in the same graph (in brown), are based on various data sets from coastal and open ocean sites in the Pacific. Very high mixing ratios, as found in this study on San Cristobal Island and Christmas Island, determine the position of the two bounding process lines and the resulting emission ratios $(0.7 ; 9)$. The relatively high $\mathrm{CHBr}_{3} / \mathrm{CH}_{2} \mathrm{Br}_{2}$ ratio of 9 may reflect the closer proximity to the sources for some of the measurements. But the high ratio of $\mathrm{CHBr}_{2} \mathrm{Cl}$ to $\mathrm{CH}_{2} \mathrm{Br}_{2}$ reported by Yokouchi et al. (2005) is clearly different from our findings, as some of the List data would lie outside of the brown dashed dilution line based on that study. Deviations in the calibration scale for $\mathrm{CHBr}_{2} \mathrm{Cl}$ and/or differences in the emission ratios between the different source regions could be plausible explanations for these differences. Measurements at the Cape Verde Islands (results added in green), evaluated with the same method by O'Brien et al. (2009), also revealed an emission ratio of 9 for $\mathrm{CHBr}_{3} / \mathrm{CH}_{2} \mathrm{Br}_{2}$, but a somewhat smaller ratio of 0.46 for $\mathrm{CHBr} 2 \mathrm{Cl} / \mathrm{CH}_{2} \mathrm{Br}_{2}$.

The lifetime values used for the calculation of the chemical decay line in the above analysis are estimates based on average tropospheric conditions (Ko et al., 2003). These values have been updated in the new WMO report to 24, 59 and 123 days for $\mathrm{CHBr}_{3}, \mathrm{CHBr}_{2} \mathrm{Cl}$ and $\mathrm{CH}_{2} \mathrm{Br}_{2}$ (Montzka et al., 2011). The updated lifetimes yield a different slope for the chemical decay line of 3.80. Furthermore, the relatively high near-surface temperatures in the tropics favour 


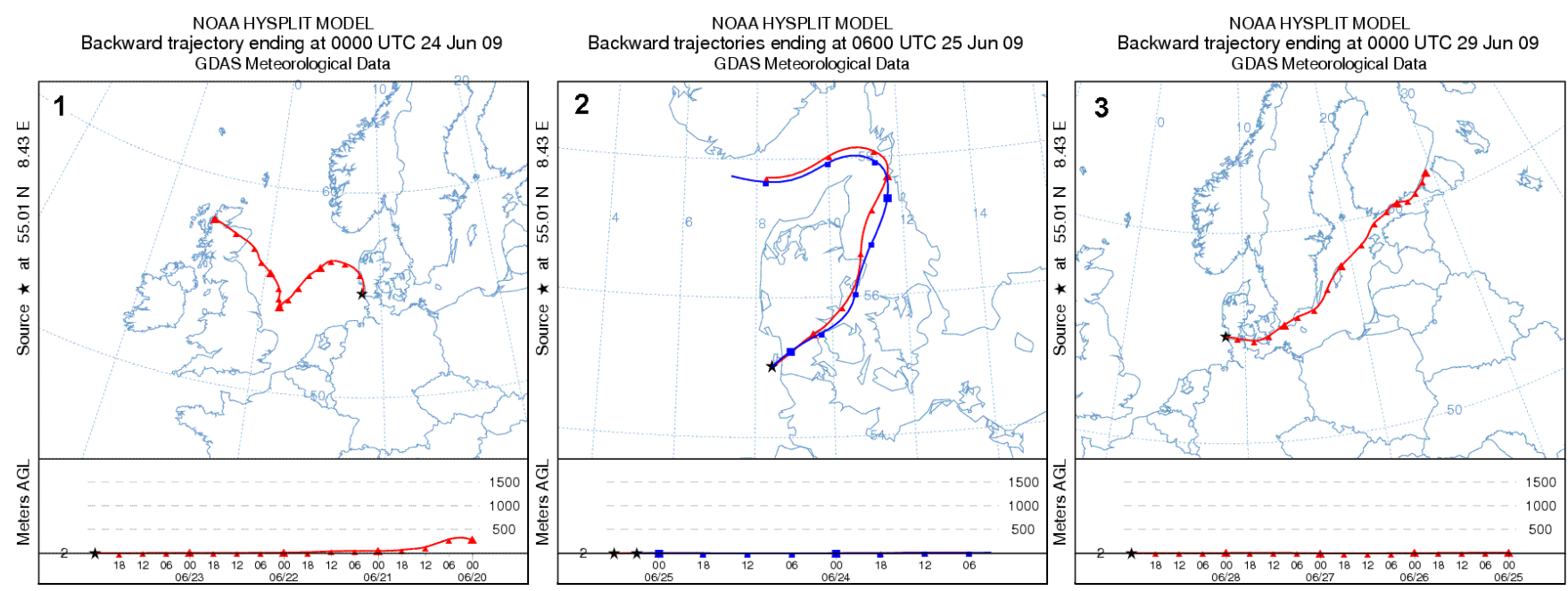

Fig. 9. Four-day backward trajectories for 24 and 29 June (left and right panel) 2009 00:00 UTC using HYSPLIT model and the FDAS global meteorological dataset provided by the NOAA (http://ready.arl.noaa.gov/HYSPLIT.php). The middle plot shows corresponding twoday backward trajectories for 25 June, ending at 03:00 (blue line) and 06:00 UTC (red line), the times of considerably elevated bromocarbon levels.
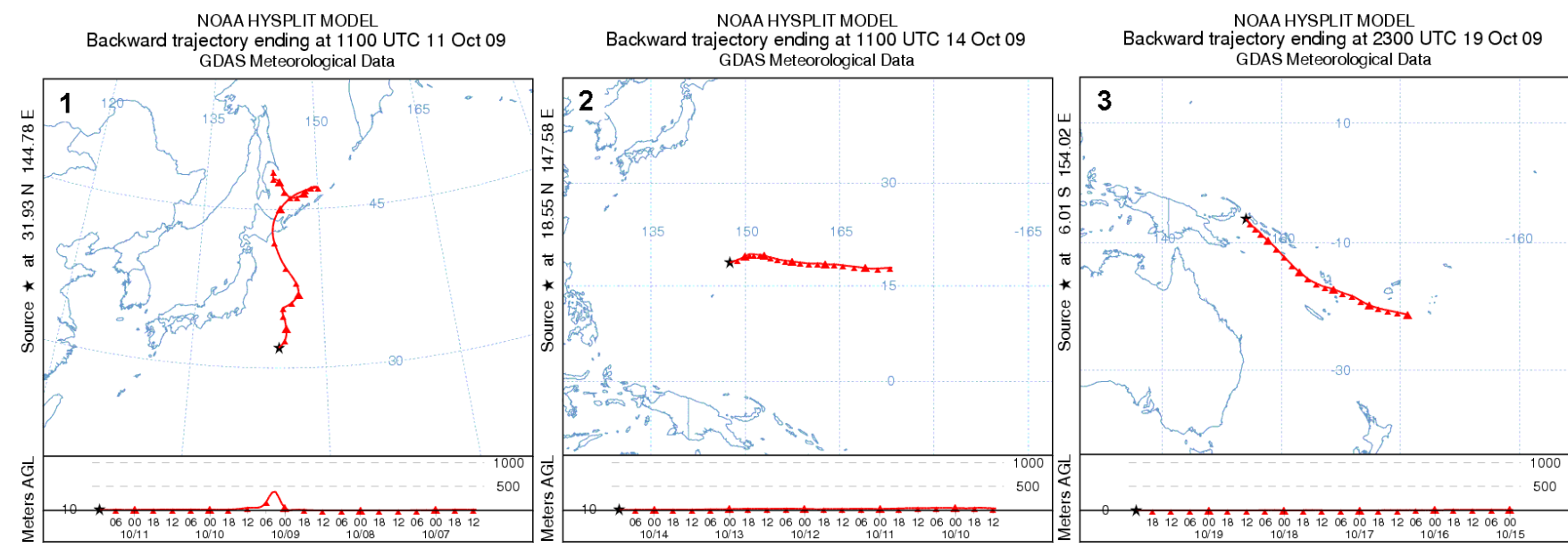

Fig. 10. Five-day backward trajectories for three sampling sites along the cruise in Western Pacific using HYSPLIT model and the FNL global meteorological dataset from NOAA.

the degradation rate especially of $\mathrm{CH}_{2} \mathrm{Br}_{2}$ relative to $\mathrm{CHBr}_{3}$, as shown by Hossaini et al. (2010), who calculated local lifetimes of 52 days for $\mathrm{CH}_{2} \mathrm{Br}_{2}$ and 16 days for $\mathrm{CHBr}_{3}$ in these regions. Using these values and an estimate of 29 days for the corresponding lifetime of $\mathrm{CHBr}_{2} \mathrm{Cl}$, the slope of the chemical decay line is even lower $(2.84)$. $\left(\tau_{\mathrm{CHBr}_{2} \mathrm{Cl}}\right.$ was derived under the assumption of the same relative lifetime ratio

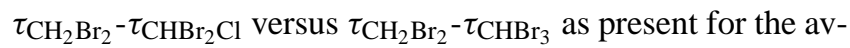
erage tropospheric values according to Montzka et al., 2011.) This modified line is shown in black dashes. With the additional assumption of a somewhat higher position of the dilution line so that it would match an emission ratio of 9 for $\mathrm{CHBr}_{3} / \mathrm{CH}_{2} \mathrm{Br}_{2}$, point $\mathrm{B}$ can be placed at $(0.35,9)$. These values seem to be reasonable estimates of the initial atmo- spheric concentration ratios of the three species, considering the strong emphasis of degradation indicated for the data sets and the consistent findings from Yokouchi et al. (2005) and O'Brien et al. (2009).

Based on the global sea-to-air flux estimates of $61 \mathrm{Gg}$ $\mathrm{Br} \mathrm{yr}^{-1}$ for $\mathrm{CH}_{2} \mathrm{Br}_{2}$ (Ko et al., 2003) we derive values of 820 and $21 \mathrm{Gg} \mathrm{Br} \mathrm{yr}^{-1}$ for $\mathrm{CHBr}_{3}$ and $\mathrm{CHBr}_{2} \mathrm{Cl}$. As noted above, higher global fluxes of $\mathrm{CHBr}_{2} \mathrm{Cl}$ are likely, considering the observation of several inconsistently high values near the coastlines of the West Pacific. Under the assumption of a similar emission ratio for $\mathrm{CHBrCl}_{2}$ compared to $\mathrm{CHBr}_{2} \mathrm{Cl}$, as indicated by the regression slope analysis, the global $\mathrm{Br}$ flux from $\mathrm{CHBrCl}_{2}$ is calculated to be $11 \mathrm{Gg} \mathrm{yr}^{-1}$. The flux estimates for $\mathrm{CH}_{2} \mathrm{Br}_{2}$ that we use here are near the lower 

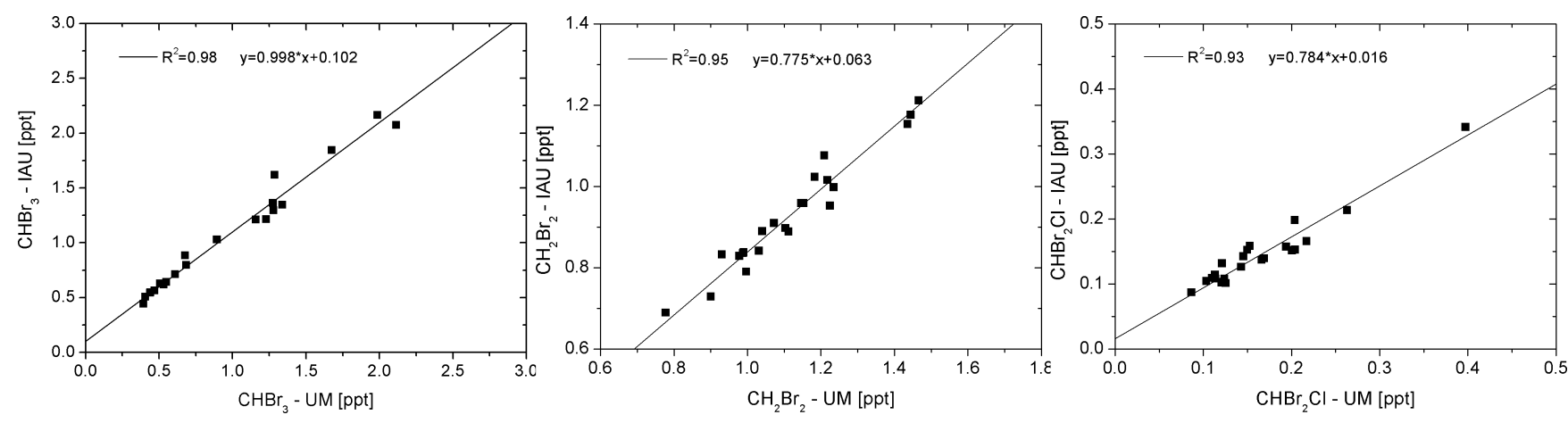

Fig. 11. Linear orthogonal regression of IAU data versus UM data collected in parallel for $\mathrm{CHBr}_{3}(\mathrm{left}), \mathrm{CH}_{2} \mathrm{Br}_{2}(\mathrm{middle})$ and $\mathrm{CHBr} 2 \mathrm{Cl}$ (right panel). The corresponding determination coefficients $R^{2}$ and the regression equations are listed in the plots.

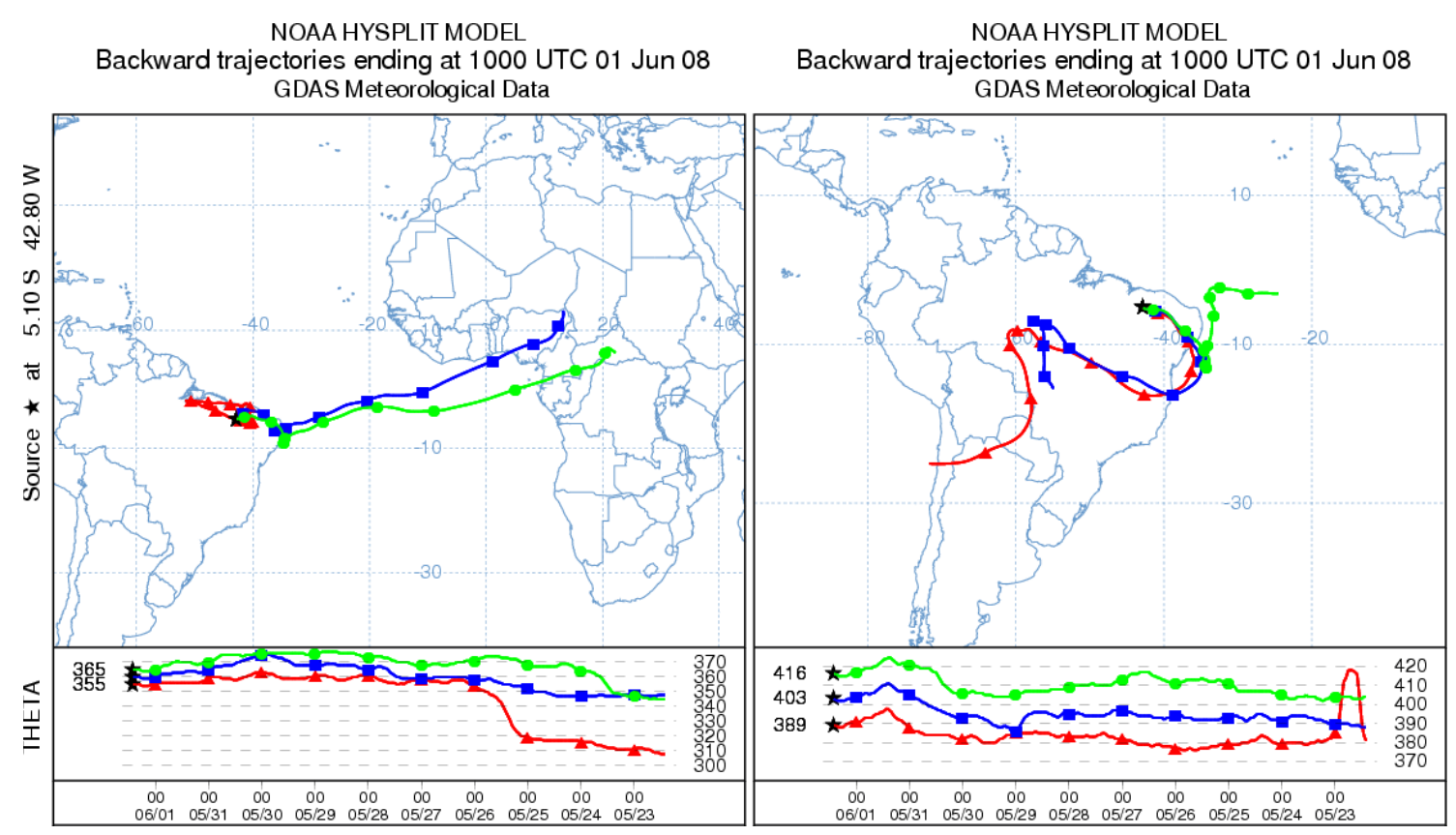

Fig. 12. 10-day backward trajectories for 1 June 200810 UTC, left: for $14.5 \mathrm{~km}$ (red), $15.0 \mathrm{~km}$ (blue) and $15.5 \mathrm{~km}$ (green), right: for $17.0 \mathrm{~km}$ (red), $17.5 \mathrm{~km}$ (blue) and $18.0 \mathrm{~km}$ (green) above Teresina using HYSPLIT model and the FDAS global meteorological dataset provided by the NOAA.

end of a range of other estimates from 57 to $280{\mathrm{Gg} \mathrm{Br} \mathrm{yr}^{-1}}^{-1}$ (Liang et al., 2010; Butler et al., 2007; Montzka et al., 2011), which indicates large uncertainties for these global fluxes and the absolute values derived above for the other species.

\section{Observations TTL}

\subsection{Results}

One of the two TTL samples above Teresina originates from an altitude of $14.8 \mathrm{~km}(135.6 \mathrm{hPa}, T=197.1 \mathrm{~K}, \theta=$ $349.1 \mathrm{~K}$ ), which is very close to the level of zero radiative heating (LZRH) (see e.g. Fueglistaler et al., 2009). The second sample was collected slightly above the cold point tropopause at $17.5 \mathrm{~km}, 85.3 \mathrm{hPa}, T=192.6 \mathrm{~K}, \theta=389.4 \mathrm{~K}$. As the LZRH marks a boundary between mainly downward motion below and typically ascending air masses above, an air parcel exceeding this level is expected to be lifted into the stratosphere. According to Gettelman et al. (2004) the LZRH is typically found at $15 \mathrm{~km}$ altitude, $125 \mathrm{hPa}$ air pressure, $200 \mathrm{~K}$ temperature and $360 \mathrm{~K}$ potential temperature. In the same study a very small range of temperatures (between 198 and $201 \mathrm{~K}$ ) for the LZRH was found (from five different profiles in the TTL), while the other attributes of the LZRH (altitude, pressure, potential temperature) exhibited a larger spread. These observations emphasise the strong impact of water vapour mixing ratios, which are fixed by 
Table 6. Comparison of mixing ratios and $1 \sigma$ measurement precisions of the five important brominated VSLS, analysed for the two TTL samples at 14.8 and $17.5 \mathrm{~km}$ altitude. The values give the best estimates based on the measurements on both laboratory GC-MS systems Si-1 and AG-7890.

\begin{tabular}{lcc}
\hline Compound & $\begin{array}{c}\text { B44-15(14.85 km) } \\
\text { [ppt] }\end{array}$ & $\begin{array}{c}\text { B44-12 (17.47 km) } \\
\text { [ppt] }\end{array}$ \\
\hline $\mathrm{CH}_{2} \mathrm{Br}_{2}$ & $0.726 \pm 0.012$ & $0.537 \pm 0.009$ \\
$\mathrm{CHBr}_{3}$ & $0.188 \pm 0.007$ & $0.040 \pm 0.002$ \\
$\mathrm{CHBrCl}_{2}$ & $0.083 \pm 0.002$ & $0.055 \pm 0.002$ \\
$\mathrm{CH}_{2} \mathrm{BrCl}$ & $0.082 \pm 0.002$ & $0.067 \pm 0.002$ \\
$\mathrm{CHBr}_{2} \mathrm{Cl}$ & $0.036 \pm 0.001$ & $0.017 \pm 0.001$ \\
\hline
\end{tabular}

temperature (Hartmann and Larson, 2002), on the determination of the LZRH. Based on the Gettleman et al. (2004) estimates, the lowest air sample of the Teresina flight (collected at $T=197 \mathrm{~K}$ ) originates from a region very close to this dynamical boundary. Figure 12 displays the 10-day backward trajectories for different altitudes around $15 \mathrm{~km}$ (left panel) and around $17.5 \mathrm{~km}$ (right panel) above Teresina for the date of the flight. We find stronger horizontal movements and a very slow upward motion (see levels of potential temperatures along the trajectories in the plots), as expected for the TTL. However, it is well known that the vertical motion of kinematic trajectories (derived from pressure tendency of the underlying meteorological data set), as used by the HYSPLIT model, can deviate considerably from the real motion in the upper troposphere and the TTL (e.g. Ploeger et al., 2010). A spread is visible for the trajectories in both graphs; thus we can not reliably assign source regions for the two air samples.

The results of the analysis of the two TTL air samples for the five brominated VSLS are listed in Table 6. As expected, the measurements demonstrate a strong vertical gradient of VSLS mixing ratios in the TTL (especially for $\mathrm{CHBr}_{3}$ ). The mixing ratio gradients are caused by degradation of the source gases during the relatively slow vertical transport. The product gases from decomposition processes above the LZRH may contribute significantly to the stratospheric bromine budget, since they are not efficiently scavenged from the TTL region. Removal processes for VSLS product gases are linked with cloud formation and precipitation which are expected to be less effective at these altitudes. Thus, the air sample near the LZRH should yield a good estimate of the amount of bromine injected into the stratosphere by the different source gases.

In Table 7 the budget of organic bromine for the air sample near the LZRH is listed. For molecules with multiple bromine atoms the initial source gas mixing ratio is multiplied with the number of bromine atoms in order to derive total bromine. Assuming that the investigated air mass is lifted to the upper stratosphere without removal of bromine
Table 7. Budget of organic bromine $\left(\mathrm{Br}_{\mathrm{org}}\right)$ near the LZRH for balloon flight B44 in Teresina. The listed uncertainties include measurement precisions as well as calibration uncertainties. Possible temporal drifts of the concentrations are not considered (see discussion in the text).

\begin{tabular}{|c|c|c|c|}
\hline \multirow[t]{2}{*}{ Compound } & \multicolumn{3}{|c|}{ Teresina $200814.8 \mathrm{~km}$} \\
\hline & $\begin{array}{l}\text { Mix. Ratio } \\
{[\mathrm{ppt}]}\end{array}$ & $\begin{array}{l}\mathrm{Br}_{\text {org }} \\
{[\mathrm{ppt}]}\end{array}$ & $\begin{array}{c}\text { Uncert. } \\
\text { [ppt] }\end{array}$ \\
\hline Halon-1211 & 4.240 & 4.240 & \pm 0.035 \\
\hline Halon-1301 & 3.022 & 3.022 & \pm 0.138 \\
\hline Halon-2402 & 0.422 & 0.844 & \pm 0.048 \\
\hline Halon-1202 & 0.030 & 0.060 & \pm 0.008 \\
\hline $\mathrm{CH}_{3} \mathrm{Br}$ & 7.397 & 7.397 & \pm 0.191 \\
\hline $\mathrm{CH}_{2} \mathrm{Br}_{2}$ & 0.726 & 1.452 & \pm 0.120 \\
\hline $\mathrm{CHBr}_{3}$ & 0.188 & 0.564 & \pm 0.069 \\
\hline $\mathrm{CHBrCl}_{2}$ & 0.083 & 0.083 & \pm 0.018 \\
\hline $\mathrm{CH}_{2} \mathrm{BrCl}$ & 0.082 & 0.082 & \pm 0.019 \\
\hline \multirow[t]{4}{*}{$\mathrm{CHBr}_{2} \mathrm{Cl}$} & 0.036 & 0.072 & \pm 0.016 \\
\hline & Elong-lived: & 15.56 & \pm 0.42 \\
\hline & EVSLS: & 2.25 & \pm 0.24 \\
\hline & Total: & 17.82 & \pm 0.66 \\
\hline
\end{tabular}

or mixing with ambient air, a complete degradation of all source gases would convert this bromine bound to organic compounds $\left(\mathrm{Br}_{\text {org }}\right)$ to a corresponding mixing ratio of inorganic bromine $\left(\mathrm{Br}_{\mathrm{y}}\right)$. We find a total of $17.82 \mathrm{ppt}$ with a major contribution of $41 \%$ from methyl bromide $\left(\mathrm{CHBr}_{3}\right)$, while the sum of the halons yields a relative amount of $46 \%$. The remaining fraction of $2.25 \mathrm{ppt}(12.6 \%)$ is attributed to the five VSLS.

As mentioned in Sect. 2.2, the concentrations of $\mathrm{CH}_{3} \mathrm{Br}$, $\mathrm{CH}_{2} \mathrm{Br}_{2}$ and $\mathrm{CHBr}_{3}$ showed significant declines after one year of storage in the BONBON canisters. When assuming a linear drift between the date of sampling and the date of the repeated measurement, the initial mixing ratios of $\mathrm{CH}_{3} \mathrm{Br}$, $\mathrm{CH}_{2} \mathrm{Br}_{2}$ and $\mathrm{CHBr}_{3}$ would have been 3,2 and $14 \%$ higher at the time of the sampling than determined by the measurements. This would result in an additional $0.11 \mathrm{ppt}$ bromine from the two VSLS in the budget set up for the air sample near the LZRH. These values are assumed to represent best estimates of the maximum error caused by sample instabilities. The very high pressure of around 30 bar has certainly stabilised the conditions in the canisters prior to the first measurements, so that the presumption of an exponential decay (as indicated by the investigations of the two-liter canisters in Sect. 2.2) would lead to a strong overestimation of this error. This assumption of relatively stable conditions at the beginning is supported by the outcomes of the four consecutive analyses on the two instruments, conducted within five weeks starting about one month after the sampling. During these measurements no significant decay of the brominated VSLS was observed. 


\subsection{Comparison and discussion}

The budget of bromine obtained in a region near the LZRH indicates that the VSLS have a considerable impact on the stratospheric content of inorganic bromine. According to our data, approximately half of the unassigned stratospheric bromine of about 3-7 ppt (Dorf et al., 2006) could be explained by the injection of bromine originating from VSLS, if we assume no removal processes above the LZRH and that our samples are representative of the global average of air entering the stratosphere. Considering the distance of the sampling site to the ITCZ regions (with deep convection and fast ascent of air masses), there is potential for a larger contribution from VSLS to the stratospheric bromine budget than indicated by our measurements.

During a former balloon flight in June 2005 in Teresina the VSLS mixing ratios (analysed for an air sample at $15.2 \mathrm{~km}$ ) were considerably lower than those analysed in 2008 at nearly the same altitude (Laube et al., 2008). The total $\mathrm{Br}_{\text {org }}$ from VSLS was $1.25 \mathrm{ppt}$, while especially the $\mathrm{CHBr}_{3}$ contribution was unexpectedly low, with only $0.05 \mathrm{ppt} \mathrm{Br}_{\text {org }}$. This comparison and the comparison with the available data from other studies (e.g. Schauffler et al., 1999; Sinnhuber and Folkins, 2006) indicate that the variabilities of the VSLS concentrations are relatively high in the TTL, due to variations of the source emissions and of the related transport processes into the TTL. Nevertheless, in the specific case of the 2005 Teresina sample, we expect a considerable decay of the VSLS in the BONBON canisters during storage of 8 months between sampling and measurements. Considering the relative decreases as observed between initial and repeated measurement for Teresina 2008, the VSLS budget 2005 could be underestimated by up to $0.3 \mathrm{ppt}$.

Little knowledge exists about the relative importance of the product gas injection, the transport of organic or inorganic products from the decomposition of $\mathrm{CH}_{3} \mathrm{Br}$ and the brominated VSLS to the stratosphere. The high mixing ratio gradients observed for $\mathrm{CHBr}_{3}$ and other VSLS in the TTL indicate a strong degradation of these substances between the LZRH and the cold-point tropopause and also below the LZRH. This raises the important question of the extent to which these product gases are affected by possible removal processes in the TTL. Even though removal by precipitation is expected to be relatively rare in the layer above the level of main convective outflow at $14 \mathrm{~km}$, the reservoir gas $\mathrm{HBr}$ (the typical degradation product under tropospheric conditions), with a high solubility in water and a significant uptake coefficient on ice (Law et al., 2007), can be efficiently removed by singular events of convective overshooting. Additional removal can be caused by falling ice particles, which form during the dehydration of rising air parcels up to the coldpoint tropopause (e.g. Sinnhuber and Folkins, 2006). On the other hand, inorganic bromine already present near the LZRH could compensate for the loss of $\mathrm{Br}_{\mathrm{y}}$ produced and
Table 8. Comparison of estimated SGI and PGI (in ppt Br) for the five brominated VSLS, in a simple approach derived from the two TTL samples at 14.8 and $17.5 \mathrm{~km}$ (see Table 6).

\begin{tabular}{lccc}
\hline Compound & SGI+PGI & SGI & SGI Relative \\
\hline $\mathrm{CH}_{2} \mathrm{Br}_{2}$ & 1.452 & 1.074 & $74 \%$ \\
$\mathrm{CHBr}_{3}$ & 0.564 & 0.120 & $21 \%$ \\
$\mathrm{CHBrCl}_{2}$ & 0.083 & 0.055 & $66 \%$ \\
$\mathrm{CH}_{2} \mathrm{BrCl}$ & 0.082 & 0.067 & $82 \%$ \\
$\mathrm{CHBr}_{2} \mathrm{Cl}$ & 0.072 & 0.034 & $47 \%$ \\
\hline Total VSLS & 2.253 & 1.350 & $60 \%$ \\
\hline
\end{tabular}

washed-out during the transport to the cold-point tropopause.

In a simple approach we can assume our VSLS source gas data at $17.5 \mathrm{~km}$ as representative for the source gas injection (SGI) into the stratosphere and the values measured at $14.8 \mathrm{~km}$ as the sum of SGI and PGI (product gas injection). The corresponding results from this calculation are listed in Table 8. As expected, we find the highest relative amount of SGI (versus total $\mathrm{Br}$ injection) for the relatively longer-lived compounds $\mathrm{CH}_{2} \mathrm{Br}_{2}$ and $\mathrm{CH}_{2} \mathrm{BrCl}$ with 74 and $82 \%$, respectively. For the shortest-lived $\mathrm{CHBr}_{3}$ only $21 \%$ of the bromine molecules would be transported directly via SGI across the tropopause, while the remaining $79 \%$ would be bound to the different products following the decomposition of $\mathrm{CHBr}_{3}$ in the TTL. Since the sample at $17.5 \mathrm{~km}$ was collected somewhat above the tropopause and the product gases are potentially affected by removal processes in the TTL, the relative contribution from SGI to the total transport of bromine into the stratosphere is probably somewhat higher than estimated above. Using the chemical transport model SLIMCAT and assuming different $\mathrm{Br}_{\mathrm{y}}$ lifetimes (from 10 to $\infty$ days) Hossaini et al. (2010) found similar ranges for the relative SGI of 7-32\% for $\mathrm{CHBr}_{3}$ and $62-87 \%$ for $\mathrm{CH}_{2} \mathrm{Br}_{2}$. The corresponding absolute values derived from this global modelling study are also in a fair agreement with our rough estimates.

\section{Conclusions}

With our measurements we can extend the database for all five relevant brominated VSLS in the source regions and at the transition to the stratosphere. The Western Pacific data clearly emphasise the importance of coastal sources, as the mixing ratios of the short-lived bromocarbons considerably drop above the open ocean. Strong correlations, as found between $\mathrm{CHBr}_{3}, \mathrm{CH}_{2} \mathrm{Br}_{2}, \mathrm{CHBr}_{2} \mathrm{Cl}$ and $\mathrm{CHBrCl}_{2}$, indicate emissions from the same sources with consistent emission ratios. Using an approach by McKeen and Liu (1993) and comparing the results with the findings from former studies, we derive estimates of $9 / 1 / 0.35 / 0.35$ for the initial atmospheric concentration ratios of $\mathrm{CHBr}_{3}$, 
$\mathrm{CH}_{2} \mathrm{Br}_{2}, \mathrm{CHBr}_{2} \mathrm{Cl}$ and $\mathrm{CHBrCl}_{2}$. The poor correlation with the other bromine species indicates that different sources are important for $\mathrm{CH}_{2} \mathrm{BrCl}$. Several of the coastal air samples in the Western Pacific suggest the presence of an additional independent source or a higher emission ratio for $\mathrm{CHBr}_{2} \mathrm{Cl}$ in these specific regions.

The results of the TTL measurements above Teresina indicate a significant contribution from brominated VSLS to the stratospheric bromine. Based on the budget of organic bromine near the LZRH (at $14.8 \mathrm{~km}$ ) we estimate the amount of bromine transported by VSLS in this region at the time of the flight to be $2.25 \mathrm{ppt}$. This would make up $13 \%$ of total organic bromine (17.82 ppt), with $\mathrm{CH}_{2} \mathrm{Br}_{2}$ (1.45 ppt) and $\mathrm{CHBr}_{3}$ (0.56 ppt) accounting for $90 \%$ of the VSLS budget. These values are near the lower end of the range of about 37 ppt derived from stratospheric BrO measurements (Dorf et al., 2006). The comparison with former measurements in the same TTL region and with the findings from other studies indicates a relatively high variability of the VSLS mixing ratios in the TTL. Measurements with higher spatial and temporal resolution are needed to obtain a more precise picture of the global contribution of brominated VSLS to stratospheric bromine, especially in the West Pacific region - an area identified to be of major importance for the global transport into the stratosphere.

Acknowledgements. We thank K. Krüger for the organisation of the TransBrom campaign, furthermore C. Müller, H. Quack and A. Lanatowitz for the collection of the samples. E. Atlas likes to acknowledge X. Zhu and L. Pope for technical support during the sample analyses at Miami. Financial support from the European commission under the project SHIVA (grant no. 226224) are acknowledged as well as the funding and support by the International Max Planck Research School (IMPRS) for Atmospheric Chemistry and Physics. Additionally we like to thank J. Williams and the MPI Mainz for providing the sample canisters during the campaigns List and TransBrom.

Edited by: M. Dameris

\section{References}

Atlas, E., Pollock, W., Greenberg, J., Heidt, L., and Thompson, A.: Alkyl Nitrates, Nonmethane Hydrocarbons, and Halocarbon Gases Over the Equatorial Pacific Ocean During Saga 3, J. Geophys. Res., 98, 16933-16947, 1993.

Aschmann, J., Sinnhuber, B.-M., Atlas, E. L., and Schauffler, S. M.: Modeling the transport of very short-lived substances into the tropical upper troposphere and lower stratosphere, Atmos. Chem. Phys., 9, 9237-9247, doi:10.5194/acp-9-9237-2009, 2009.

Butler, J. H., King, D. B., Lobert, J. M., Montzka, S. A., YvonLewis, S. A., Hall, B. D., Warwick, N. J., Mondeel, D. J., Aydin, M., and Elkins, J. W.: Oceanic distributions and emissions of short-lived halocarbons, Global Biogeochem. Cy., 21, GB1023, doi:10.1029/2006GB002732, 2007.
Carpenter, L. J., Liss, P. S., and Penkett, S. A.: Marine organohalogens in the atmosphere over the Atlantic and Southern Oceans, J. Geophys. Res., 108, 4256, doi:10.1029/2002JD002769, 2003.

Carpenter, L. J., Wevill, D. J., O'Doherty, S., Spain, G., and Simmonds, P. G.: Atmospheric bromoform at Mace Head, Ireland: seasonality and evidence for a peatland source, Atmos. Chem. Phys., 5, 2927-2934, doi:10.5194/acp-5-2927-2005, 2005.

Carpenter, L. J., Wevill, D. J., Hopkins, J. R., Dunk, R. M., Jones, C. E., Hornsby, K. E., and McQuaid, J. B.: Bromoform in tropical Atlantic air from $25^{\circ} \mathrm{N}$ to $25^{\circ} \mathrm{S}$, Geophys. Res. Lett., 34, L11810, doi:10.1029/2007GL029893, 2007.

Class, T. and Ballschmiter, K.: Chemistry of Organic Traces in Air, VIII: Sources and Distribution of Bromo- and Bromochloromethanes in Marine Air and Surfacewater of the Atlantic Ocean, J. Atmos. Chem., 6, 35-46, 1988.

Dorf, M., Butler, J. H., Butz, A., Camy-Peyret, C., Chipperfield, M. P., Kritten, L., Montzka, S. A., Simmes, B., Weidner, F., and Pfeilsticker, K.: Long-term observations of stratospheric bromine reveal slow down in growth, Geophys. Res. Lett., 33, L24803, doi:10.1029/2006GL027714, 2006.

Fueglistaler, S., Wernli, H., and Peter, T.: Tropical troposphereto-stratosphere transport inferred from trajectory calculations, J. Geophys. Res., 109, D03108, doi:10.1029/2003JD004069, 2004.

Fueglistaler, S., Dessler, A. E., Dunkerton, T. J., Folkins, I., Fu, Q., and Mote, P. W.: Tropical tropopause layer, Rev. Geophys., 47, RG1004, doi:10.1029/2008RG000267, 2009.

Gettelman, A., Salby, M. L., and Sassi, F.: The distribution and influence of convection in the tropical tropopause region, J. Geophys. Res., 107, 4080, doi:10.1029/2001JD001048, 2002.

Gettelman, A., de F. Forster, P. M., Fujiwara, M., Fu, Q., Vömel, H., Gohar, L. K., Johanson, C., and Ammerman, M.: Radiation balance of the tropical tropopause layer, J. Geophys. Res., 109, D07103, doi:10.1029/2003JD004190, 2004.

Hartmann, D. L. and Larson, K.: An important constraint on tropical cloud - climate feedback, Geophys. Res. Lett., 29, 1951, doi:10.1029/2002GL015835, 2002.

Hossaini, R., Chipperfield, M. P., Monge-Sanz, B. M., Richards, N. A. D., Atlas, E., and Blake, D. R.: Bromoform and dibromomethane in the tropics: a 3-D model study of chemistry and transport, Atmos. Chem. Phys., 10, 719-735, doi:10.5194/acp10-719-2010, 2010.

Ko, M. K. W., Poulet, G., Blake, D. R., Boucher, O. Burkholder, J. H., Chin, M., Cox R., A., George, C., Graf, H.-F., Holton, J. R., Jacob, D. J., Law, K. S., Lawrence, M. G., Midgley, P. M., Seakins, P. W., Shallcross, D. E., Strahan, S. E., Wuebbles, D. J., and Yokouchi, Y.: Very short-lived halogen and sulfur substances, Scientific assessment of ozone depletion: 2002, Global Ozone Research and Monitoring Project. Report No. 47, Chapter 2, World Meteorological Organization, Geneva, 2003.

Krüger, K. and Quack, B.: Introduction to special issue: the TransBrom Sonne expedition in the tropical West Pacific, Atmos. Chem. Phys. Discuss., 12, 1401-1418, doi:10.5194/acpd12-1401-2012, 2012.

Laube, J. C., Engel, A., Bönisch, H., Möbius, T., Worton, D. R., Sturges, W. T., Grunow, K., and Schmidt, U.: Contribution of very short-lived organic substances to stratospheric chlorine and bromine in the tropics - a case study, Atmos. Chem. Phys., 8, 7325-7334, doi:10.5194/acp-8-7325-2008, 2008.

Law, K. S., Sturges, W. T., Blake, D. R., Blake, N. J., Burkholder, 
J. B., Butler, J. H., Cox, R. A., Haynes, P. H., Ko, M. K. W., Kreher, K., Mari, C., Pfeilsticker, K., Plane, J. M. C., Salawitch, R. J., Schiller, C., Sinnhuber, B.-M., von Glasow, R., Warwick, N. J., Wuebbles, D. J., and Yvon-Lewis, S. A.: Halogenated very short-lived substances, Scientific assessment of ozone depletion: 2006, Global Ozone Research and Monitoring Project. Report No. 50, Chapter 2, World Meteorological Organization, Geneva, 2007.

Li, S.-M., Yokouchi, Y., Barrie, L., Muthuramu, K., Shepson, P., Bottenheim, J., Sturges, W., and Landsberger, S.: Organic and inorganic bromine compounds and their composition in the Arctic troposphere during polar sunrise, J. Geophys. Res., 99, 2541525428, 1994.

Liang, Q., Stolarski, R. S., Kawa, S. R., Nielsen, J. E., Douglass, A. R., Rodriguez, J. M., Blake, D. R., Atlas, E. L., and Ott, L. E.: Finding the missing stratospheric Bry: a global modeling study of $\mathrm{CHBr}_{3}$ and $\mathrm{CH}_{2} \mathrm{Br}_{2}$, Atmos. Chem. Phys., 10, 2269-2286, doi:10.5194/acp-10-2269-2010, 2010.

McKeen, S. A. and Liu, S. C.: Hydrocarbon ratios and photochemical history of air masses, Geophys. Res. Lett., 20, 2363-2366, 1993.

Montzka, S. A., Reimann, S., Engel, A., Krüger, K., O’Doherty, S., Sturges, W. T., Blake, D., Dorf, M., Fraser, P., Froidevaux, L., Jucks, K., Kreher, K., Kurylo, M. J., Mellouki, A., Miller, J., Nielsen, O.-J., Orkin, V. L., Prinn, R. G., Rhew, R., Santee, M. L., Stohl, A., and Verdonik, D.: Ozone-Depleting Substances (ODSs) and Related Chemicals, Chapter 1, Scientific Assessment of Ozone Depletion: 2010, Global Ozone Research and Monitoring Project, World Meteorological Organization, Geneva, Switzerland, 2011.

O’Brien, L. M., Harris, N. R. P., Robinson, A. D., Gostlow, B., Warwick, N., Yang, X., and Pyle, J. A.: Bromocarbons in the tropical marine boundary layer at the Cape Verde Observatory - measurements and modelling, Atmos. Chem. Phys., 9, 90839099, doi:10.5194/acp-9-9083-2009, 2009.

Parrish, D. D., Hahn, C. J., Williams, E. J., Norton, R. B., Fehsenfeld, F. C., Singh, H. B., Shetter, J. D., Gandrud, B. W., and Ridley, B. A.: Indications of photochemical histories of pacific air masses from measurements of atmospheric trace species at Point Arena, California, J. Geophys. Res., 97, 15883-15902, 1992.

Ploeger, F., Konopka, P., Günther, G., Grooß, J.-U., and Müller, R.: Impact of the vertical velocity scheme on modeling transport in the tropical tropopause layer, J. Geophys. Res., 115, D03301, doi:10.1029/2009JD012023, 2010.
Quack, B. and Wallace, D. W. R.: Air-sea flux of bromoform: Controls, rates, and implications, Global Biogeochem. Cy., 17, 1023, doi:10.1029/2002GB001890, 2003.

Quack, B., Atlas, E., Petrick, G., Stroud, V., Schauffler, S., and Wallace, D. W. R.: Oceanic bromoform sources for the tropical atmosphere, Geophys. Res. Lett., 31, L23S05, doi:10.1029/2004GL020597, 2004.

Roberts, J. M., Fehsenfeld, F. C., Liu, S. C., Bollinger, M. J., Hahn, C., Albritton, D. L., and Sievers, R. E.: Measurements of aromathic hydrocarbon ratios and $\mathrm{NO}_{x}$ concentrations in the rural troposphere: Observations of air mass photochemical aging and $\mathrm{NO}_{\mathrm{x}}$ removal, Atmos. Environ., 18, 2421-2432, 1984.

Schauffler, S., Atlas, E., Blake, D., Flocke, F., Lueb, R., Lee-Taylor, J., Stroud, V., and Travnicek, W.: Distributions of brominated organic compounds in the troposphere and lower stratosphere, J. Geophys. Res., 104, 21513-21535, 1999.

Schmidt, U., Kulessa, G., Klein, E., Röth, E.-P., Fabian, P., and Borchers, R.: Intercomparison of balloon-borne cryogenic whole air samplers during the MAP/GLOBUS 1983 campaign, Planet. Space Sci., 35, 647-656, 1987.

Sinnhuber, B.-M. and Folkins, I.: Estimating the contribution of bromoform to stratospheric bromine and its relation to dehydration in the tropical tropopause layer, Atmos. Chem. Phys., 6, 4755-4761, doi:10.5194/acp-6-4755-2006, 2006.

WMO (World Meteorological Organization): Scientific Assessment of Ozone Depletion: 2006, Global Ozone Research and Monitoring Project-Report No. 50, Geneva, 2007.

Yokouchi, Y., Hasebe, F., Fujiwara, M., Takashima, H., Shiotani, M., Nishi, N., Kanaya, Y., Hashimoto, S., Fraser, P., ToomSauntry, D., Mukai, H., and Nojiri, Y.: Correlations and emission ratios among bromoform, dibromochloromethane, and dibromomethane in the atmosphere, J. Geophys. Res., 110, D23309, doi:10.1029/2005JD006303, 2005.

Zhou, Y., Mao, H., Russo, R. S., Blake, D. R., Wingenter, O. W., Haase, K. B., Ambrose, J., Varner, R. K., Talbot, R., and Sive, B. C.: Bromoform and dibromomethane measurements in the seacoast region of New Hampshire, 2002-2004, J. Geophys. Res., 113, D08305, doi:10.1029/2007JD009103, 2008. 